\title{
Development of a Computer Model for Calculation of Radioactive Materials into the Atmosphere After an Accident
}

\author{
V. Schershakov
}

November 1997

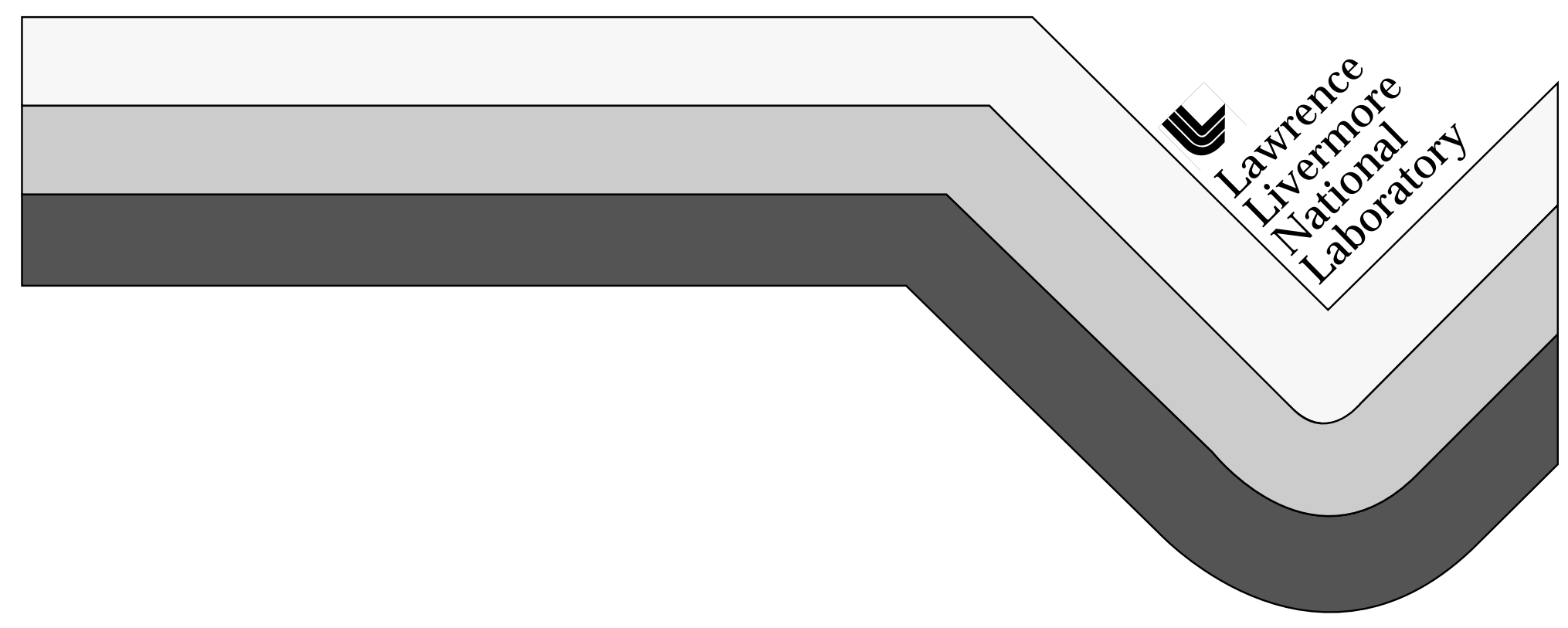




\section{DISCLAIMER}

This document was prepared as an account of work sponsored by an agency of the United States Government. Neither the United States Government nor the University of California nor any of their employees, makes any warranty, express or implied, or assumes any legal liability or responsibility for the accuracy, completeness, or usefulness of any information, apparatus, product, or process disclosed, or represents that its use would not infringe privately owned rights. Reference herein to any specific commercial product, process, or service by trade name, trademark, manufacturer, or otherwise, does not necessarily constitute or imply its endorsement, recommendation, or favoring by the United States Government or the University of California. The views and opinions of authors expressed herein do not necessarily state or reflect those of the United States Government or the University of California, and shall not be used for advertising or product endorsement purposes.

Work performed under the auspices of the U.S. Department of Energy by Lawrence Livermore National Laboratory under Contract W-7405-ENG-48. 


\section{FEDERAL INFORMATION-ANALYTICAL CENTRE}

Science and Production Association "Typhoon"

Development of a computer model for calculation of resuspension of radioactive materials into the atmosphere after an accident

Report on contract 1B 336474

Supervisor of works under the contract

Deputy General Director of SPA'Typhoon"

Schershakov V.

Obninsk 



\section{List of specialists involved:}

Head of FIAC department, PHD

Head of FIAC Laboratory, PHD

Leading Researcher, PHD

Senior researcher, PHD

Researcher

Programmer

Technician

Translator
O.I.Voszhennikov

Scientific leader of works

under contract 1B336474

K.I.Vasilyeva

Responsible Specialist

P.N.Svirkunov

Executing specialist

S.A.Nikonov

Programming

\author{
A.I.Burkov \\ Executing specialist \\ E.A.Morozko \\ Executing specialist
}

G.P.Kurlanova

Presentation of material

E.L.Mikhailova

Translation 


\section{Contents}

pp.

INTRODUCTION $\ldots \ldots \ldots \ldots \ldots .4$

1. Resuspension factor ........ 5

2. Resuspension rate .. 12

2.1. Methods of estimating resuspension rate ............. 12

2.2. Experimental and calculation data on resuspension rate . . . . 13

2.3. Resuspension of radioactive dust particles in the air due to anthropogenic activities . . . . . . . . . 19

2.4. Doses due to wind and mechanical resuspension of radioactive dust . . 22

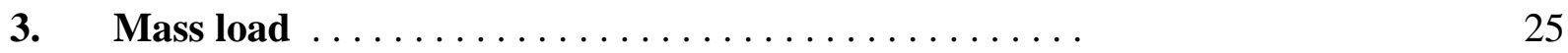

4. Calculation formulae for characteristics of wind resuspension $\begin{array}{ll}\text { of radioactive dust . } & 28\end{array}$

4.1. Formulae to calculate resuspension rate and resuspension factor . . . 28

4.2. Estimation of mechanical resuspension rate . . . . . . . . . 34

4.3. Comparison of calculated values $\alpha$ and $R$ with experimental . . . 35

5. Methodology for estimating the resuspension rate and resuspension factor and the flux of radioactive dust from the underlying surface $\ldots \ldots \ldots \ldots \ldots \ldots$.

5.1. Input parameters required for calculation . . . . . . . 44

5.2. Roughness length .............. 44

5.3. Calculation of the resuspension factor and resuspension rate . . . . 46

5.4. Flux of radioactive dust from the underlying surface . . . . . . . 46

5.5. Calculation of wind resuspension characteristics using the mass load method . . . . . . . . . . . . . 47

5.5.1. Input parameters for calculation with the mass load method . . . . . . 47

5.5.2. Calculation of the resuspension factor, resuspension rate and flux of radioactive dust ..... 47

6. About estimation of atmospheric contamination with burning radioactive materials ........ 50

Conclusion ....... 54

APPENDIX. Description of program module RESUSP . . . 55 


\section{INTRODUCTION}

Secondary atmospheric contamination with radioactive dust and chemical species deposited on the ground and resuspended by wind occur very widely. This process is particularly pronounced in case of extensive contamination of soil and under extreme weather conditions, for example, during dust storms.

The mechanism of wind dust generation consists in the following. At low wind speed $U=2-3 \mathrm{~m} / \mathrm{s}$, which is most common in midlatitude, small radioactive dust particles (diameter of hundredth of a micron to $10 \div 20$ microns) are lifted from soil surface due to turbulent vortexes. Under the gravitational force the particles of 1-2 micron diameter practically do not settle. Larger dust particles cannot remain in the air for a long time: they are lifted by turbulent vortexes and settle, their motion in the wind flow is jumpwise and the interaction of particles with the flow is called saltation /1/. Saltation is the main mechanism of dust generation up to the wind velocity at which wind erosion starts. The size of dust particles can be as large as $100 \mu \mathrm{m}$. When dropping they can be ricocheting from ground or pass the impulse to other particles which begin rolling over and jumping up. The process of dust transport by wind can be compared to a chain reaction. At the velocity of $10 \mathrm{~m} / \mathrm{s}$ large particles of about $500 \mu \mathrm{m}$ stop skipping and roll over only, while particles of more than $1 \mathrm{~mm}$ remain stationary. Thus, the fine fraction is blown out from the polydispersed soil particles.

The intensity of wind resuspension of radioactive dust from the ground is characterized either by a resuspension factor or a resuspension rate.

The resuspension factor $/ 2 /$ is determined as a ratio of radionuclides concentration in the air at a reference level (usually $1 \mathrm{~m}$ ) and surface contamination density measured in $\mathrm{m}^{-1}$.

$$
R=\frac{q_{1}}{A}, \mathrm{~m}^{-1}
$$

where $q_{1}, \mathrm{~Bq} / \mathrm{m}^{3}$ is the average radionuclide concentration in the air at height $1 \mathrm{~m}$;

$A, \mathrm{~Bq} / \mathrm{m}^{2}$ is the surface contamination density.

The resuspension rate $/ 2 /$ is found as a fraction of contaminating species, in particular radionuclides, on the ground which is lifted into the air in time unit either under the wind action only or under mechanical action on the surface

$$
\alpha=\frac{Q}{A}, \mathrm{~s}^{-1}
$$


where $Q,[\mathrm{~Bq} /(\mathrm{m} 2 \cdot \mathrm{s})]$ is the turbulent radionuclides flow near the ground. 


\section{Resuspension factor}

The main advantage of this coefficient is its simplicity and the fact that most measurements of resuspension are expressed in this form $/ 2,3 /$. The disadvantage is that the formulae are empirical, which makes difficult extrapolation of results with generalization, ignoring spatial distribution of contamination and size of contaminated area.

The analysis of the first experimental data using the resuspension factor for dust contaminated by $P u$ has shown that under mechanical disturbances it lies in the range $2 \cdot 10^{-6}{ }_{-}$ $7 \cdot 10^{-5} \mathrm{~m}^{-1}$. Given no mechanical disturbances and for a relatively fresh deposited material, the resuspension factor was measured to be within $10^{-8}-210^{-6} \mathrm{~m}^{-1}$ and for the aged species - within $6 \cdot 10^{-10} \div 10^{-13} \mathrm{~m}^{-1} / 2 /$.

The data on plutonium fixation in soil in the climatic conditions of the Nevada testing grounds (semi-desert) have permitted describing the change in the resuspension factor with time as $/ 3 /$

$$
R(t)=R(0) \exp \left(-0,15 t^{1 / 2}\right)+10^{-9},
$$

where $t$ is time in days. The initial value $R(0)$ is taken to be $10^{-4} \mathrm{~m}^{-1}$.

With the same material /4/ the following empirical expression was derived

$$
R(t)=10^{-5} \exp \left[\left(-1,46 \cdot 10^{-7}-2,2 \cdot 10^{-10}-\lambda\right) t\right]+10^{-3} \exp \left[\left(-2,2 \cdot 10^{-10}-\lambda\right) t\right]
$$

where $t$ is given in days, $\lambda$ is the radioactive decay constant.

On the one hand, formula (1.4) is preferable to (1.3) as the resuspension factor $R(t)$ tends to zero with time, which matches the physical meaning of the process. On the other hand, the radioactive decay constant $\lambda$ is incorporated in (1.4) formally. It is clear that with a phase-type contamination the resuspension factor $R$ cannot depend on $\lambda$, as the radionuclide in the air and soil decays at equal rate.

In subsequent studies related to reactor safety and environmental behaviour of radionuclides $/ 5 /$ the following expressions for $R(t)$ were used

$$
\begin{aligned}
& R(t)=10^{-5} \exp (-0,0139 t)+10^{-9}, \\
& R(t)=10^{-5} \exp (-0,00185 t)+10^{-9},
\end{aligned}
$$

where $t$ is time since the contamination, day.

A simple formula for $R(t)$ was proposed in $/ 5 /$ for the wet climate conditions of UK: 


$$
R(t)=10^{-6} \exp (-0,01 t)+10^{-9},
$$

$t$ is given in days.

In /6/ based on data about the post Chernobyl contamination and using experimental estimation and numerical modelling the following equation for the resuspension factor was derived which does not include the background value:

$$
R(t)=1,2 \cdot 10^{-6} \cdot t^{-1},
$$

where $t$ is time in days

Based on monitoring of ${ }^{137} \mathrm{Cs}$ concentration in the air and contamination density of the upper 1cm soil layer near Noirburg from mid May 1986 to the end $1987 / 7 /$ and from June 1986 to the end 1990/8/ the following expressions for $R(t)$ have been derived /8/:

$$
\begin{aligned}
& R(t)=3,4 \cdot 10^{-6} \exp (-0,152 t)+18,4 \cdot 10^{-9} \exp (-0,03 t) \\
& R(t)=2,67 \cdot 10^{-6} t^{-1,07},
\end{aligned}
$$

where $t$ is time, days.

According to expressions (3)-(8) the resuspension factor in the first 10 days after the accident varies within $10^{-6} \div 10^{-4}$. The values of the resuspension factor determined experimentally or calculated /5-9/ are shown in Table 1.1. Table 1.1 also includes the upper and lower bounds and average values of $R(t)$ and ratio of calculated and experimental values /9/. The data cover the period of 1986-1991 and the difference between the upper and the lower bounds of $R(t)$ can be as large as an order of magnitude. On a whole, the calculated data are in agreement with the experimental ones obtained in Chernobyl after 20 May 1986 and in 1987-1991.

Table 1.1

Mean annual resuspension factor measured in 1986 (after 20 May ) in Chernobyl and calculated by $/ 9 /$

\begin{tabular}{||c|c|c|c|c|c|c|c|c|c||}
\hline Year & $\begin{array}{c}\text { Lower } \\
\text { bound } \\
\text { of } R \\
\left(10^{-7} \mathrm{~m}^{-1}\right)\end{array}$ & $\begin{array}{c}\text { Mean } \\
\text { value } \\
\text { of } R \\
\left(10^{-7} \mathrm{~m}^{-1}\right)\end{array}$ & $\begin{array}{c}\text { Upper } \\
\text { bound } \\
\text { of } R \\
\left(10^{-7} \mathrm{~m}^{-1}\right)\end{array}$ & $\begin{array}{c}R_{\text {Gar }} \\
\left(10^{-7} \mathrm{~m}^{-1}\right)\end{array}$ & $\begin{array}{c}R_{\text {Hoet }} \\
\left(10^{-7} \mathrm{~m}^{-1}\right)\end{array}$ & $\begin{array}{c}R_{\text {Lin }} \\
\left(10^{-7} \mathrm{~m}^{-1}\right)\end{array}$ & $\begin{array}{l}R_{\text {Gar }} \\
R_{\exp }\end{array}$ & $\begin{array}{l}R_{\text {Hoet }} \\
R_{\exp }\end{array}$ & $\begin{array}{c}R_{\text {Lin }} \\
R_{\exp }\end{array}$ \\
\hline \hline 1986 & 0,053 & 0,330 & 0,830 & 0,270 & 0,510 & 3,90 & 0,82 & 1,54 & 11,8 \\
1987 & 0,013 & 0,082 & 0,170 & 0,030 & 0,042 & 0,27 & 0,36 & 0,51 & 3,30 \\
1988 & 0,004 & 0,032 & 0,070 & 0,014 & 0,021 & 0,016 & 0,44 & 0,66 & 0,50 \\
1989 & 0,002 & 0,014 & 0,034 & 0,010 & 0,014 & 0,010 & 0,71 & 1,00 & 0,71 \\
1990 & 0,0008 & 0,006 & 0,015 & 0,008 & 0,010 & 0,010 & 1,33 & 1,66 & 1,66 \\
1991 & 0,001 & 0,008 & 0,018 & 0,006 & 0,008 & 0,010 & 0,75 & 1,00 & 1,25 \\
\hline
\end{tabular}


$R_{\text {Gar }}$ is calculated by $/ 6 /$

$R_{\text {Hoet }}$ is calculated by $/ 8 /$

$R_{\text {Lin }}$ is calculated by /5/

$R_{\text {exp }}$ is measured in Chernobyl in 1986-1991/9/ 
It should be noted that the resuspension factor calculated based on the experimental data from the vicinity of Noirburg after the Chernobyl accident /8/ is in a better agreement than others with the Chernobyl measurements /9/. The data of /6/ are systematically lower the experimental, the data of /5/ differ significantly from the experimental ones for the first two years after the accident.

Table 1.2 shows $R(t)$ calculated by /5-9/) and measured in the $30 \mathrm{~km}$ zone around the Chernobyl NPP in 1986 and 1991. The values of $R(t)$ calculated by /6,8/ differ by an order of magnitude from the experimental ones $/ 9 /$ and $/ 5 /$ for $t=117$ days and the discrepancy in $R(t)$ is decreasing with time.

Table 1.2

Comparison of calculated and measured resuspension factors

\begin{tabular}{||l|c|c||}
\hline Data source & $\begin{array}{c}R\left(\mathrm{~m}^{-1}\right) \\
t=117 \text { day. } \\
(14-17 \text { Sept. 1986) }\end{array}$ & $\begin{array}{c}R\left(\mathrm{~m}^{-1}\right) \\
t=1957 \text { day. } \\
(25 \text { Sept. 1991) }\end{array}$ \\
\hline \hline /5/ & $31 \times 10^{-8}$ & $10 \times 10^{-10}$ \\
/6/ & $1,1 \times 10^{-8}$ & $6,1 \times 10^{-10}$ \\
/8/ & $1,6 \times 10^{-8}$ & $8,0 \times 10^{-10}$ \\
Experimental & & First point: \\
data /9/ & ${ }^{137} \mathrm{Cs}^{\mathrm{a}}:(17 \pm 19) \times 10^{-8}$ & ${ }^{137} \mathrm{Cs}:(4,3 \pm 2,2) \times 10^{-10}$ \\
& ${ }^{106} \mathrm{Ru}:(23 \pm 16) \times 10^{-8}$ & Second point: \\
& ${ }^{144} \mathrm{Ce}:(19 \pm 24) \times 10^{-8}$ & ${ }^{137} \mathrm{Cs}^{\mathrm{b}}:(2,4 \pm 1,0) \times 10^{-10}$ \\
\hline
\end{tabular}

${ }^{a}$ is average over 10 points and three days

${ }^{\mathrm{b}}$ is mean over six cases of $R$ measurements during one day.

In /10/ based on measurements in Haunover during the first fifteen days after the primary contamination as a result of the Chernobyl accident the following values of the resuspension factor as a function of wind velocity were derived $\left(R=2 \cdot 10^{-6} \div 2 \cdot 10^{-5} \mathrm{~m}^{-1}\right)$. In $/ 11 /$ the data obtained in Haunover during 12-22 days after the accident and data of measurements in Chernobyl conducted during a longer period from June 1986 to 15008 day after the accident were generalized which permitted writing the following equation for $R(t) / 11 /$

$$
R(t)=2,09 \cdot 10^{-4}(t)^{-1,67}
$$

$t$ is time after the accident in days. In the view of the authors of $/ 11 /$, the exponent $(-1.67)$ is most suitable, considering that the reduction in radionuclides concentration in the surface soil layer is proportional to $t^{-0.5}$ and the uplift of fine particles in the eddy flow according to $/ 12 /$ is proportional to $t^{-1.07}$. 
In work /13/ based on the semi-empirical equation an explicit relation between the resuspension factor and parameters of radionuclides migration in soil was derived.

Based on the data on wind resuspension of a tracer of submicron size (calcium molibdate) /2/ which was dispersed on an experimental plot using several impactors adjusted to work at different wind velocities, an attempt was made to establish a dependence of the resuspension factor on wind speed. In particular, it is established that at the height of $1,8 \mathrm{~m}$ the resuspension factor was increasing in proportion to wind speed with exponent 6.5. It was also noticed that during 3 years the wind resuspension of the tracer was decreasing.

In work /14/ the determination of the resuspension factor is based on the assumption that the radioactivity concentration in the air $q$ is related to the measured flux of settling radionuclides $S^{*}$ through the following expression:

$$
q=S^{*} / v_{d}
$$

where $v_{d}$ is the dry deposition velocity. On the other hand, the quantity $q$ can be determined by density of soil radioactive contamination $A$ and resuspension factor

Hence,

$$
q=R \cdot A
$$

$$
R=\frac{S^{*}}{V_{d} \cdot A}
$$

According to the data of $/ 14 / A=125 \mathrm{Ci} / \mathrm{km}^{2}, S^{*}=9.4 \mathrm{~Bq} \mathrm{~m}^{2} \mathrm{~s}^{-1}$, then $R=310^{-9} \mathrm{~m}^{-1}$, the dry deposition velocity is taken to be $V_{d}=0.008 \mathrm{~m} / \mathrm{s}$. The resulting $R$ agrees with the value of the resuspension factor calculated by direct measurements in the first days and months after the Chernobyl accident

$$
\begin{array}{ll}
R=10 \cdot 10^{-9} \mathrm{~m}^{-1} & / 15 / \\
R=(0,6 \div 200) 10^{-9} \mathrm{~m}^{-1} & / 16,17 /
\end{array}
$$

In conclusion, we present data on the resuspension factor determined from measurements in the area of Chernobyl in August-September 1986/17/. Table 1.3 contains resuspension factors for some radionuclides estimated from the data of 14-17 September 1986 in separate points of the $30 \mathrm{~km}$ zone around the Chernobyl NPP. Table 1.4 shows mean resuspension factors derived based on data of August-September 1986 for the population point of Zapolie. 
Table 1.3

Wind resuspension factor on 14-17 September 1986

\begin{tabular}{||l|r|r|r|r|r|r|r|r||}
\hline \multirow{2}{*}{ Point } & \multicolumn{7}{|c||}{ Resuspension factor $\times 10^{-8}\left(\mathrm{~m}^{-1}\right)$} \\
\cline { 2 - 9 } & ${ }^{144} \mathrm{Ce}$ & \multicolumn{1}{|c||}{${ }^{141} \mathrm{Ce}$} & ${ }^{103} \mathrm{Ru}$ & ${ }^{106} \mathrm{Ru}$ & ${ }^{137} \mathrm{Cs}$ & ${ }^{134} \mathrm{Cs}$ & ${ }^{95} \mathrm{Zr}$ & ${ }^{95} \mathrm{Nb}$ \\
\hline \hline Pripyat & 9,7 & 10,0 & 11,0 & 7,6 & 7,7 & 0,9 & 8,7 & 8,5 \\
Kopachi & 85,0 & 72,0 & 60,0 & 59,0 & 59,0 & 58,0 & 64,0 & 88,0 \\
Lelev & 16,0 & 322,0 & 15,0 & 26,0 & 5,2 & 42,0 & 9,0 & 18,0 \\
Zapolie & 11,0 & 9,0 & 3,0 & 0,6 & 5,3 & 10,0 & 6,0 & 6,5 \\
Zalesye & 10,0 & 11,0 & 10,0 & 21,0 & 6,8 & 17,0 & 55,0 & 9,2 \\
Korogod & 10,0 & 23,0 & 10,0 & 28,0 & 4,2 & 11,0 & 11,0 & 9,91 \\
Opachichi & 9,0 & 7,0 & 5,6 & 21,0 & 13,0 & 21,0 & 4,0 & 6,7 \\
Yampol & 3,3 & 7,5 & 5,5 & 26,0 & 5,9 & 16,0 & 4,1 & 2,8 \\
Zimovichi & 18,0 & 10,0 & 22,0 & 30,0 & 42,0 & 120,0 & - & - \\
Chernobyl & 15,0 & 18,0 & 19,0 & 10,0 & 20,0 & 15,0 & 17,0 & 23,0 \\
& & & & & & & & \\
Mean & $18,7 \pm$ & 48,9 & 16,1 & 22,9 & 16,9 & 31,1 & 19,7 & 18,1 \\
& 7,8 & 32,6 & $\pm 5,4$ & $\pm 5,3$ & $\pm 6,2$ & $\pm 11,8$ & $\pm 8,1$ & $\pm 9,3$ \\
\hline
\end{tabular}

Table 1.4

Mean wind resuspension factors (Zapolie August/September 1986)

\begin{tabular}{||c|c|c|c|c|c|c||}
\hline \multicolumn{7}{|c||}{ Resuspension factor $\times 10^{-8}\left(\mathrm{~m}^{-1}\right)$} \\
\hline${ }^{144} \mathrm{Ce}$ & ${ }^{141} \mathrm{Ce}$ & ${ }^{103} \mathrm{Ru}$ & ${ }^{134} \mathrm{Cs}$ & ${ }^{137} \mathrm{Cs}$ & ${ }^{95} \mathrm{Zr}$ & ${ }^{95} \mathrm{Nb}$ \\
\hline \hline $7,7 \pm 3,9$ & $4,4 \pm 2,1$ & $9,9 \pm 7,5$ & $6,3 \pm 1,3$ & $7,7 \pm 2,1$ & $5,4 \pm 3,6$ & $5,5 \pm 3,7$ \\
\hline
\end{tabular}

An attempt to study the dependence of the resuspension factor on particle diameter was made in /18/ based on measurements of 1992-1993 in the population points of Novozybkov, Mikulichi, Kovali, Zapolie and on the bank of the Pripyat' river. In general, the resuspension factor has been found to increase with the growth of particle diameter.

In conclusion it is worth noting that today data are available on wind resuspension factor which have been obtained from measurements. The wind resuspension factor of ${ }^{137} \mathrm{Cs}$ in AugustSeptember 1986, on the average, was $(6.3 \pm 1.3) \cdot 10^{-8} \mathrm{~m}^{-1}$ and $0.8 \cdot 10^{-9} \mathrm{~m}^{-1}$ in 1991 , with the lower and upper bounds of the value differing from the average by as much as an order of magnitude.

Approximation expressions describing the changes in the resuspension factor with time have been obtained. Among them, the expression (1.11) derived in (11) should be pointed out. Its advantage is that it has been derived based on experimental data received in Chernobyl for more than 4 years starting from 1986 and in Haunover during 12-22 days after the accident.

Data are available on dependence of the resuspension factor on the diameter of migrating particles. The resuspension factor has been shown to grow with the increase in particles diameter. 


\section{References}

1. Fux N.A. Mechanisms of aerosols. M.:Punlishers USSR Academy of Sciences, 1955

2. Transuranium elements. Ed. by U.S.Hepson M.:Energoatomisdat, 1985, 344p.

3. Anspaugh L.R., Shinn J.H., Phelps P.L., Kenedy N.C. Resuspension and Redistribution of Plutonium in Soils., Healts Phys. v 29, 1975, _p.571-582.

4. Meteorology for Evaluation the Radiological Consequences of Radioactive Effluents Realesed in Normal Operations. NR PB and CEA, UK and France. Commission of the European Communities. Doc. 1 V/3865/79, 1973.

5. Linsley G.S. Resuspension of the Transuranium Elements. A Review of Existing Data, Natioal Radiological Protection Board, Harwell, 1978.

6. Garland G.A., Pattenden N.T., Playford K. Resuspension following Chernobyl, Expert Reviews of the Modelling of Resuspension, Seasonality and Losses during Food Processing, Validation of Environmental Model Predictions (VAMP), IAEA, Vienna, 1991.

7. Hoetzl H., Rosner G., Wincler R., Long-term behaviour of Chernobyl fallout in air and precipatation. J. Environ. Radioact. v 10, 1989, pp.157-171.

8. Hoetzl H., Rosuer G., Wincler., Sources of Present Chernobyl derived cesium concentrations in surface air and deposition samples. Sci. Total Environ., v 119, 1992, pp.231242.

9. Garger E.K., Anspaugh L.R., Shinn J.H., Hoffman F.O. A Test of Resuspension factor models against Chernobyl data Proceedings of an International Symposium on Envirinmental Impact of Radioactive Releases Organized by the International Atomic Energy Agency and Held in Vienna, 8-12 May, 1995.

10. Hollandent W. Resuspension factors of Cs-137 in Haunover after the Chernobyl accident. J. Aerosol. Sci, v 25, 1994, pp.789-792.

11. Besmis F., Garger E., Gordeev S., Hoblander W. at all. Elements of a unified prognostic model for secondary air contamination by resuspension. The radiological consequences of the Chernobyl accident. Proceedings of the first International Conference. Minsk, Belarus, 18-22 March, 1996.

12. Reeks M.W., Reed J., Hall D. On the resuspension of small particles by a turbulent flow. J. Phys. D: Appl. Phys., v 21, 1988, pp.574-589.

13. Makhon'ko K.P. Effects of deflation of radionuclides on a contaminated soil area at instantaneous and stationary atmospheric releases. Atomic energy 1984, v.56, issue1, p.47-50.

14. Drugachenook M.A., Mironov B.P., Makarevich V.N. About influence of resuspension and transport of radioactive particles on air contamination. Bulletin of Academy of Sciences of Belorus Academy of Sciences 14, 1990.

16. Garger E.K., Zhukov G.P., Sedunov Yu.S. About assessment of parameters of wind in the area of the Chernobyl NPP. Meteorology and hydrology 11, 1990.

17. Garger E.K. Air concentrations of radionuclides in the vicinity of Chernobyl and the effects of resuspension. J. Aerosol. Sci. V. 25, 1 5, 1994, pp.745-753.

18. Garger E., Gordeev S. at all. Resuspension and deposition of radionuclides under various conditions. The radiological consequences of the Chernobyl acciclent Proceeding of the first international conference. Minsk, Belarus, 18-22 March, 1996. 


\section{Resuspension rate}

Physically, the resuspension rate $\alpha$ is a rising flow of material from the ground, the contamination of which is unity, i.e. the proportion of radionuclides resuspended by wind from the ground surface in unit time. In a general case for a plane source with non-uniform surface and surface contamination density the radionuclides resuspension rate is a function of surface characteristics and meteorological conditions.

The studies on resuspension rate $\alpha$ of radioactive species from contaminated areas were initiated when nuclear testing grounds started to be used and the first results became known in $1958 / 1 /$. The authors of /1/ investigated the process of scattering of fluorescent particles poured on the ground at a low wind speed. Later on more and more researchers became interested in the radionuclides resuspension rate. In Russia the works on radionuclides resuspension from the underlying surface were initiated after the radiation accident at "Mayak" plant in Southern Urals which resulted in formation of a contaminated area (radioactive trace). The data obtained by different authors prior to the Chernobyl accident in 1986 are included in Table 2.1

Table 2.1

Data on resuspension rate received prior to 1986

\begin{tabular}{||c|c|c|c||}
\hline Location & $\begin{array}{c}\text { Radionuclide/ } \\
\text { tracer }\end{array}$ & $\begin{array}{c}\text { Resuspension } \\
\text { rate }\left(\mathrm{s}^{-1}\right)\end{array}$ & Comments \\
\hline \hline Nevada desert & in soil & $2.7 \times 10^{-12} \div 4.8 \times 10^{-10}$ & Aged deposit /2/ \\
South Carolina & in soil & $4.3 \times 10^{-12}$ & Aged deposit /3/ \\
Nevada desert & $P u$ & $10^{-8} \div 10^{-12}$ & $\begin{array}{c}\text { Review of data /4/ } \\
\text { Deposit on grass. } \\
\text { Hanford }\end{array}$ \\
tracer & $5 r 0^{-9} \div 6 \times 10^{-8}$ & $\begin{array}{c}\text { Wind speed } 1 \mathrm{~m} / \mathrm{s} / 4 / \\
\text { Contamination of soil } \\
\text { in } 1957 \div 1960 / 5 /\end{array}$ \\
\hline
\end{tabular}

After the Chernobyl accident in April 1986 the resuspension studies have been carried out systematically by many researchers.

2.1. Methods of estimating resuspension rate.

Estimation of $\alpha$ can be done by several ways: 
1) direct measurements of vertical turbulent flows of radionuclides above uniform and stationary sources;

2) gradient measurements of average wind speed, average air temperature and average radionuclides concentration in the near-surface atmospheric layer, which makes possible assessment of the vertical turbulent flow of radionuclides from a plane uniform stationary source;

3) measurements of radionuclides concentration in the air at a fixed height outside a limited source or directly above the source;

4) measurements of depositions on a collector at a certain height. This method is based on the assumption about equality of two steady- state flows of radioactive dust: the one directed from the underlying surface to the atmosphere and that from the atmosphere to the underlying surface.

The first method has not been used widely as for its implementation unique equipment is required. The second and the third methods call for using diffusion models of varying complexity and measurements of meteorological parameters, soil contamination density and atmospheric concentration of radionuclides /6-12/.

In addition to the above methods it has been proposed in /12/ to estimate the value of town-averaged $\alpha$ by dust advection, i.e. as a ratio of horizontal dust flux from this source obtained by measurement of radionuclides concentration profile to the height at which the concentration is zero and density of deposited contamination.

\subsection{Experimental and calculation data on resuspension rate.}

After the Chernobyl accident in 1986 wind migration of radionuclides has been studied by numerical modelling and direct measurements in the contaminated areas of Russia (Bryansk region), Ukraine and Belorus.

Practically all researchers indicate a decrease in the resuspension rate with time which is explicable by radionuclides migration down the soil profile.

The results of ${ }^{137}$ Cs measurements in the atmosphere in March-April 1987-1989 allowed establishing a dependence of radioactive dust resuspension rate from the ground on time /13/:

$$
\alpha=\alpha_{0} \exp (-2.1 t)
$$

where $t$ is given in years, $\alpha$ is the value in September 1986 . The obtained exponent in $/ 2.1 /$ is in good agreement with the value 1.9 derived earlier in /6/ based on the measurements in springsummer 1958-1961 in the area affected by the accident at "Mayak" in Southern Urals in 1957. It 
should be noted that the time dependence of $\alpha$ cited in /6/ was derived for a limited time interval ( $t \leq 3$ years). This limitation also applies to equation (2.1 ).

The resuspension rate $\alpha$ varies in a wide range during a year, its value depending on meteorological conditions, condition of the underlying surface and migrating radionuclide. The vegetation cover is also an important factor influencing the resuspension rate. The vegetation cover equivalent includes the amount of vegetation in the equation of air-dried biomass matter, total frontal vegetation cross-section area, and vegetation orientation. The erect vegetation tends to reduce the wind speed near the ground and lower the resuspension rate. In /14/ empirical dependencies of resuspension rate $\alpha$ on vegetation height $h$ and mass $m$ of air-dried hay collected from unit soil surface in water have been derived

$$
\begin{aligned}
& \alpha=\frac{2.5 \cdot 10^{-9}}{h^{1.4}}, \mathrm{~s}^{-1}, \\
& \alpha=\frac{2.9 \cdot 10^{-8}}{m^{1.4}}, \mathrm{~s}^{-1},
\end{aligned}
$$

where $h$ is expressed in $\mathrm{cm}, m$ in $\mathrm{g} / \mathrm{m}^{2}$. The same work /14/ includes an empirical expression of dependence of $\alpha$ on roughness length $z_{0}$ of the underlying surface

$$
\alpha=\frac{2.0 \cdot 10^{-10}}{z_{0}^{1.4}}, \mathrm{~s}^{-1}
$$

where $z_{0}$ is given in $\mathrm{cm}$.

The presented empirical expressions have been derived for a plane (forest steppe piedmont of Southern Urals) under usual weather conditions of the central part of Russia for the average wind speed at the vane level of $2 \div 6 \mathrm{~m} / \mathrm{s}$ based on observational results in the radioactive trace in 1957 after the accident at "Mayak". In /13/ the similarity in curves $\alpha(t)$ for resuspension of fresh radioactive species from soil surface in piedmont of Southern Urals and Northern Ukraine have been noted. There is a good correlation between $\alpha$ and the degree of development of vegetation inhibiting resuspension.

The increase in the resuspension rate with wind speed has been noted by many researchers $/ 15,17 /$. In the studies of tracer resuspension with the use of submicron particles of calcium molibdate scattered on a sparsely vegetated area with roughness length $z_{0}=3.4 \mathrm{~cm} \mathrm{a}$ 
relation between resuspension rate $\alpha$ and wind speed $u$ measured at height $2,1 \mathrm{~m}$ has been derived /15/:

$$
\alpha=1,96 \cdot 10^{-13} u^{4,82}
$$

$u$ is given in $\mathrm{m} / \mathrm{s}$. Assuming that the observations were made under neutral stratification, (2.5) can be written as /15/

$$
\alpha=2 \cdot 10^{-16} u^{4,82}
$$

where $u_{*}$ is friction velocity.

Expression (2.5) has been derived by processing data at wind velocities $8-10 \mathrm{~m} / \mathrm{s}$ and for wind velocities $1-6 \mathrm{~m} / \mathrm{s}$ the following expression has been proposed $/ 15,16$ /

$$
\alpha=0,74 \cdot 10^{-10} u^{1,94} .
$$

In /17/ the dependence of resuspension rate on wind speed has been studied using the diffusion model and field measurements. The values of $\alpha$ were determined for different wind speeds by measuring 3-hour ${ }^{137} \mathrm{Cs}$ concentrations in the air and deposition flux and using model calculations of $\alpha$. The measurements were conducted in Novozybkov in 1992-1993. Using the derived values of $\alpha$ approximation expressions for $\alpha$ dependence on wind speed at the vane level were found:

$$
\begin{array}{ll}
\alpha=10^{-10} u^{1,2} & \text { at } \quad u=1 \div 3 \mathrm{~m} / \mathrm{s} \\
\alpha=0,3 \cdot 10^{-10} u^{2,9} & \text { at } \quad u=4 \div 6 \mathrm{~m} / \mathrm{s}
\end{array}
$$

$$
\alpha=0,02 \cdot 10^{-11} u^{5} \quad \text { at } \quad u=8 \div 10 \mathrm{~m} / \mathrm{s} \text {. }
$$

This is, in fact, all the information available regarding the relations of the resuspension rate and relevant parameters which influence it. In addition to the above expressions there are numerous experimental data which were used to determine the value of $\alpha$ by different ways at different time after the Chernobyl accident in different areas, yet these are for the atmospheric conditions close to neutral stratification. 
In /12/ based on the measurements made in 1986 on the western edge of Chernobyl the values were derived in three ways: by gradient measurements, by dust advection from the source and by measurements of the deposition flux. The data of /12/ are shown in Table 2.2.

The underlying surface was partly a field with grass of 30-40 cm height and partly an area with rare bushes, trees and barns. The measurements were conducted during 3 days, in the first day the soil was wet and in the following two days- dry; the wind speed at the height of $1 \mathrm{~m}$ did not exceed $2.1 \mathrm{~m} / \mathrm{s}$. On the average, according to /12/ in July 1986 the resuspension rate was $2 \cdot 10^{-8} \mathrm{~s}^{-1}$ for coarse dust $(\mathrm{Ce}-134, \mathrm{Zr}-95, \mathrm{Nb}-96) ; 4 \cdot 10^{-8} \mathrm{~s}^{-1}$ for fine dust $(\mathrm{Ru}-103, \mathrm{Cs}-137)$ and $4 \cdot 10^{-6} \mathrm{~s}^{-1}$ for $I-131 / 12 /$. 
Table 2.2

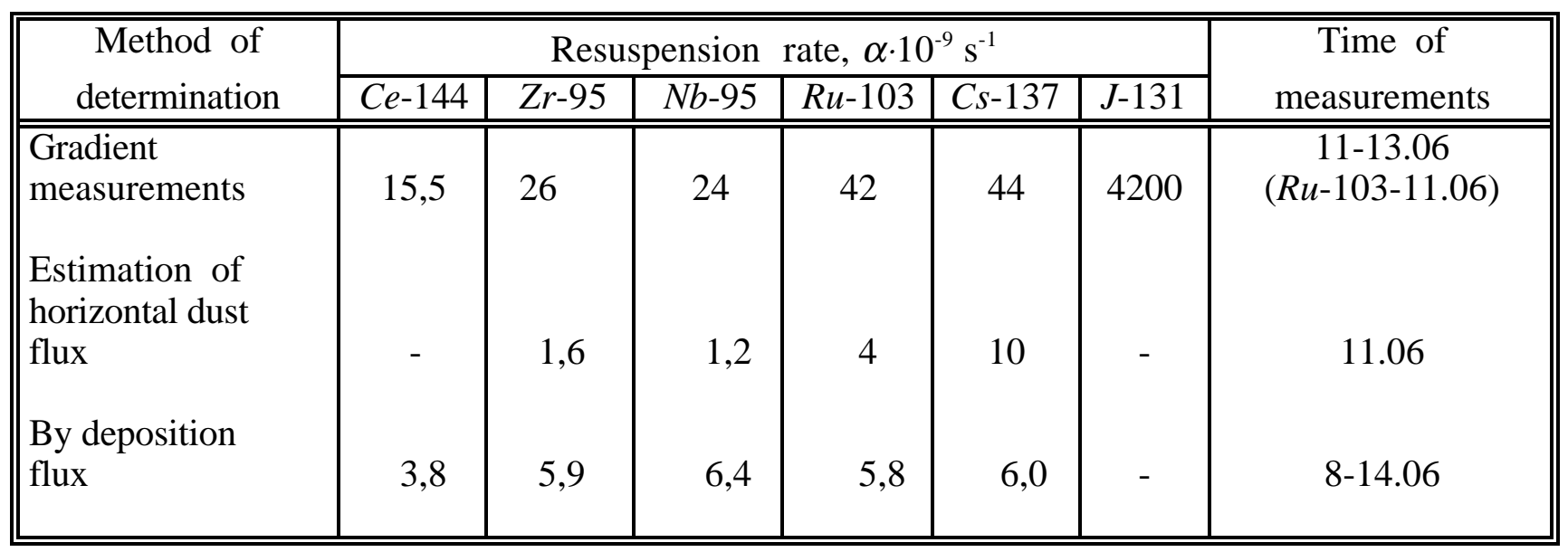

In /8/ the gradient method was used to measure the flux of radioactive dust and simultaneously wind speed at heights 4,0 and $15,0 \mathrm{~m}$. The measurements were made in JulyAugust 1992 in the area of Verteby (about $10 \mathrm{~km}$ south-west of Novozybkov) in the ${ }^{137} \mathrm{Cs}$ contaminated field under rye. The values of $\alpha$ calculated by the measured data are in the range $(1.2 \div 1.5) 10^{-9} \mathrm{~s}^{-1}$ and $(7 \div 8.6) 10^{-11} \mathrm{~s}^{-1}$, given the contamination density is calculated by ${ }^{137} \mathrm{Cs}$ inventory in the upper $1 \mathrm{~cm}$ and $20 \mathrm{~cm}$ layer, respectively. The average wind speed was 2.2-2.8 $\mathrm{m} / \mathrm{s}$ at the height of $15 \mathrm{~m}$, the soil remained dry during the measurements.

In /19/ in numerical experiments using measurements of meteoparameters and ${ }^{137} \mathrm{Cs}$ contamination density the resuspension rate in July 1992 was $2.24-2.410^{-10} \mathrm{~s}^{-1}$.

In /20/ a method has been proposed to determine the resuspension rate from concentration measurements at one level (in one point) which is the extension of the gradient method. This method is based on the fact that for a limited size of a dust-generating surface there is a height at which the concentration turns into zero, if the hypothesis on the finite velocity of turbulent scattering of material is adopted. The proposed method has been applied to estimate the resuspension rate and resuspension factor using measurements of concentration in the area of Novozybkov in April-May 1992. The radioactive aerosols were sampled on a gauze collector and a filter manufactured in "Typhoon". The average parameters of resuspension calculated by these data are $R=10^{-10} \mathrm{~m}^{-1}, \quad \alpha=10^{-11} \mathrm{~s}^{-1}$.

Extensive data on resuspension have been obtained by the authors of /1, 9, 10, 21, 22/ using ten-years observational series in the contaminated areas formed after the Chernobyl accident in 1986. Most of the experimental data were obtained by the gradient method. Table 2.3 /9, 10/ contains the resuspension rates obtained in September-October 1986 for different types of the 
underlying surface: former arable field covered by grass, young pine forest with average tree height 5-6m, and the sandy bank of the Pripyt' river. 
Table 2.3

Resuspension rate as a function of type of the underlying surface $/ 9,10 /$

\begin{tabular}{||c|c|c|c||}
\hline \multirow{2}{*}{$\begin{array}{c}\text { Type } \\
\text { of surface }\end{array}$} & \multicolumn{3}{|c|}{ Resuspension rate $\times 10^{-9}\left(\mathrm{~s}^{-1}\right)$} \\
\cline { 2 - 4 } & ${ }^{144} \tilde{N} \stackrel{\circ}{ }$ & ${ }^{137} \mathrm{Cs}$ & ${ }^{95} \mathrm{Zr}+{ }^{95} \mathrm{Nb}$ \\
\hline \hline Field & $0.3 \pm 0.1$ & $1.0 \pm 0.7$ & $0.4 \pm 0.2$ \\
Forest & $2.1 \pm 0.9$ & $2.1 \pm 0.8$ & $3.7 \pm 0.9$ \\
Pripyat bank & 2.2 & 3.7 & 2.4 \\
\hline
\end{tabular}

The data of table 2.3 show a systematic difference in the values of $\alpha$ for field, forest and beach. The values of $\alpha$ for forest are higher those for field by a factor of 2 to 9 . The high values of resuspension rate is most probably attributed to the fact that the radionuclides depositions were fresh and did not migrate down the soil profile, it is also due to the fact that the dust-generating area is greater than in the forest which has a considerable canopy. The difference in the resuspension rate for field and beach is explained by the difference in the roughness length, which is lower in the latter case. The data were obtained for dry underlying surface, the average wind speed being $\sim 2 \mathrm{~m} / \mathrm{s}$ at the height of $1 \mathrm{~m}$.

Table 2.4 and $2.5 / 21,22 /$ include data on resuspension rate for 1992-94. The data were obtained for different anthropogenic activities, and mobility of people and using different methods of measuring airborne concentration of radioactive dust. It has been pointed out in /21/ that intense agricultural activities and movement of people can lead to a change in the resuspension rate by $1-2$ orders of magnitude. This can be seen from the data for Zapolie $(0.605 .93 \div 10.05 .93)$ and on the bank of the Pripyt $(14.07 .92 \div 16.07 .92)$. 
${ }^{137} \mathrm{Cs}$ or $[\mathrm{Pu}]$ resuspension rate

\begin{tabular}{||l|c||}
\hline \multicolumn{1}{|c|}{ Site } & ${\text { Resuspension rate, } \mathrm{s}^{-1}}^{|c| \mid}$ \\
\hline \hline Zapolie 1992 & $1.1 \times 10^{-13}$ \\
Beach Pripyat & $1.1 \times 10^{-11}$ \\
Zapolie 1993 & $1.7 \times 10^{-12}\left[3.1 \times 10^{-12}\right]$ \\
Novozybkov & $4.4 \times 10^{-13}$ \\
Kovali & $1.3 \times 10^{-11}$ \\
\hline
\end{tabular}

The data of Table 2.5 show that the magnitude of resuspension rate depends on measuring equipment, and the difference in data may be as large as several orders of magnitudes.

Table 2.5

Resuspension rate for ${ }^{137} \mathrm{Cs}$

\begin{tabular}{|c|c|c|c|c|c|}
\hline \multirow[b]{2}{*}{ Site } & \multirow[b]{2}{*}{ Date } & \multicolumn{4}{|c|}{ "Means $\alpha \cdot 10^{-10}, \mathrm{~s}^{-1}$} \\
\hline & & Cone & $\begin{array}{c}\text { impactor+A广̃ } 10 \\
\text { GRAD }\end{array}$ & $\begin{array}{c}\text { aspiration } \\
\text { devices }\end{array}$ & $\begin{array}{l}\text { gauze } \\
\text { collector }\end{array}$ \\
\hline$\overline{\overline{\text { Zapolie }}}$ & $13.05 .92 \div 11.08 .92$ & $4.20 \pm 0.16$ & & "0.0011 & \\
\hline Beach Pripyat & $14.07 .92 \div 11.08 .92$ & $0.08 \pm 0.07$ & & 0.11 & \\
\hline & $06.05 .93 \div 01.06 .92$ & $1.60 \pm 1.20$ & $0.8 \pm 0.7$ & 0.017 & \\
\hline Kopachi & $28.07 .93 \div 03.08 .93$ & & & & 0.44 \\
\hline Novozybkov & $17.05 .94 \div 24.05 .94$ & & & 0.0044 & 4.6 \\
\hline Mikulichi & $13.07 .94 \div 29.07 .94$ & & & 0.13 & 0.09 \\
\hline
\end{tabular}

On a whole, the resuspension rate from the underlying surface covered by grass according to data of $/ 9,10,21,22 /$ has decreased from $1 \cdot 10^{-9} \mathrm{~s}^{-1}$ to $1.6 \cdot 10^{-10}$ (see Table 2.3, 2.4 and 2.5).

The works on resuspension rate suggest the dependence of this process on soil moisture. The attempts to estimate this dependence are made in /13, 23/. In /13/ the coefficients accounting for the effect on concentration of mineral dust in the air, the soil surface state, wind gradation and anthropogenic activity were obtained experimentally. The data are shown in Table 2.6. 
Coefficients of effects of mineral dust in the air on concentration

\begin{tabular}{||c|c|c|c|c|c|c|c|c||}
\hline \multicolumn{3}{|c|}{$\begin{array}{c}\text { Soil } \\
\text { surface }\end{array}$} & \multicolumn{3}{c|}{ Wind } & \multicolumn{3}{c||}{$\begin{array}{c}\text { Anthropogenic } \\
\text { activity }\end{array}$} \\
\hline dry & moist & wet & weak & moderate & strong & $\begin{array}{c}\text { work } \\
\text { days }\end{array}$ & $\begin{array}{c}\text { week } \\
\text { end }\end{array}$ & $\begin{array}{c}\text { intense agricul } \\
\text { tural works }\end{array}$ \\
\hline \hline 1.0 & 0.55 & 0.45 & 1.0 & 1.3 & 1.5 & 1.0 & 0.75 & 1.7 \\
\hline \hline
\end{tabular}

In /23/ based on the physico-statistical analysis of data of systematic observations of radioactive contamination of the near-surface atmosphere, meteorological conditions in the summer-autumn period of 1992-1993 in Novozybkov and its vicinity, a scheme has been proposed for prediction of ${ }^{137}$ Cs concentration in the air from data of standard agricultural and meteorological observations. The governing parameters for a specific area in the warm time of the year at regular speeds were the water content of the upper soil layer with allowance for precipitation, increased anthropogenic activity and mean daily wind direction. The latter is because the territory around Novozybkov from where radioactive dust can be transported is contaminated non-uniformly from $4 \cdot 10^{4}$ to above $1,40 \cdot 10^{6} \mathrm{~Bq} / \mathrm{m}^{2}$. The relation of the radioactive dust concentration $q_{n}$ and the above parameters is proposed to be

$$
q=(q / C)_{m} C_{0} \cdot K_{e} \cdot K_{p} \cdot K_{x} \cdot K_{v}
$$

where $q, C$ is ${ }^{137} C s$ and dust concentration in the air, respectively; $(q / C)_{\mathrm{m}}$ is specific mean activity of ${ }^{137} \mathrm{Cs}$ in the air-born dust in the observational period, $C_{0}$ is mean concentration of the air-born mineral component in dust; $K_{e}$ is coefficient accounting for water content of soil; $K_{p}$ is coefficient accounting for anthropogenic activity, $K_{x}$ is coefficient accounting for agricultural works; $K_{v}$ is wind direction.

The coefficients $K_{m}$ at $m=e, p, x$ are determined as a ratio of sample averaged concentrations $\bar{q}$ or $\bar{C}$ and corresponding value of concentration in the most frequent cases $\left(m=m_{0}\right)$

The comparison of the calculated and observed concentrations of ${ }^{137} \mathrm{Cs}$ in the air has shown good agreement.

2.3. Resuspension of radioactive dust particles in the air due to anthropogenic activities.

The resuspension associated with mechanical disturbances of the underlying surface which is hereinafter referred to as mechanical resuspension in accordance with /10/ depends on the magnitude of the force applied, its nature, the depth of the layer to which the action is exerted and wind speed. The first experiments on mechanical resuspension of tracer $Z n S$ (see/15/) during 
walking of a man along an asphalt road $3 \mathrm{~m}$ wide and $15 \mathrm{~m}$ long covered with the tracer have shown that the values of mechanical resuspension rate vary significantly and may be higher the wind resuspension rate by a factor of 100 . The results of the analysis of air samples collected when working the field contaminated with $P u$ and used for calculation of wind resuspension rates have shown that the wind resuspension rate during the agricultural operations depend on the type of the operation, field area and meteorological conditions and vary in a wide range $10^{-6} \div 10^{-8} \mathrm{~s}^{-1}$ during sowing and with vegetation removed; $4 \cdot 10^{-8}-6 \cdot 10^{-8} \mathrm{~s}^{-1}$ with disking and $3 \cdot 10^{-9} 4 \cdot 10$ $7 \mathrm{~s}^{-1}$ with harrowing.

In $/ 21,22 /$ the wind resuspension rate during agricultural works in the fields contaminated after the Chernobyl accident was estimated with experimental data and numerical modelling. The starting data for modelling were specific measured values of surface contamination density 1.2; 0.45; $0.56 \mathrm{mBq} / \mathrm{m}^{2}$ near Novozybkov, Mikulichi and Kovali, respectively and the meteorological characteristics obtained in 1994. The results of numerical modelling as airborne concentrations of radionuclides $q$, fluxes of radioactive particles of diameters less than $10 \mu \mathrm{m}$ and more than $15 \mu \mathrm{m}$ from the unit surface and wind resuspension rate calculated by these fluxes and emission rates of the particles are presented in Table 2.7. 
Table 2.7

Radionuclides concentration in the air $(q)$, flux of radioactive dust ( $Q$ ), mechanical resuspension $(\alpha)$.

\begin{tabular}{|c|c|c|c|c|}
\hline $\begin{array}{c}\text { Site and date } \\
\text { of experimental data }\end{array}$ & $q\left(\mathrm{mBq} \mathrm{m}^{-3}\right)$ & $\begin{array}{l}Q(<10 \mu \mathrm{m}) \\
\left(\mathrm{mBq} \mathrm{s}^{-1} \mathrm{~m}^{-2}\right) \\
\end{array}$ & $\begin{array}{l}Q(>15 \mu \mathrm{m}) \\
\left(\mathrm{mBq} \mathrm{s}{ }^{-1} \mathrm{~m}^{-2}\right) \\
\end{array}$ & $\alpha\left(\mathrm{s}^{-1}\right)$ \\
\hline $\begin{array}{c}\text { Novozybkov } \\
13.5\end{array}$ & 19.3 & - & 8.1 & $6.8 \cdot 10^{-9}$ \\
\hline 14.5 & 43.5 & - & 20.4 & $1.7 \cdot 10^{-8}$ \\
\hline 14.5 & 39.9 & - & 16.3 & $1.4 \cdot 10^{-8}$ \\
\hline 17.5 & 11.7 & - & 5.3 & $4.4 \cdot 10^{-8}$ \\
\hline $\begin{array}{c}\text { Mikulichi } \\
30.7\end{array}$ & 25.6 & 0.2 & 5.5 & \\
\hline 31.7 & 8.7 & 0.4 & 1.2 & $1.4 \cdot 10^{-8}$ \\
\hline 01.8 & 30.7 & 1.6 & 4.7 & $3.8 \cdot 10^{-8}$ \\
\hline 02.8 & 127.0 & 0.9 & 20.6 & $1.5 \cdot 10^{-8}$ \\
\hline $\begin{array}{c}\text { Kovali } \\
06.8\end{array}$ & 5.6 & 0.3 & 0.8 & $5.1 \cdot 10^{-8}$ \\
\hline & & & & $2.0 \cdot 10^{-9}$ \\
\hline
\end{tabular}

The mean mechanical resuspension rate in this case is $\sim(1.5 \pm 0.6) \cdot 10^{-8} \mathrm{~s}^{-1}$ which is several orders of magnitude higher the wind resuspension rate. The data in Table 2.7 show that the flux from the soil of particles of diameter $(d)$ more than $15 \mu \mathrm{m}$ is much larger than the flux of smaller particles, i.e. the derived mechanical resuspension rate should rather be referred to resuspension of particles with $d>15 \mu \mathrm{m}$. Work /21/ indicates that the flux of radionuclides from unit length in Zapolie (10 km from Chernobyl) in the spring 1993 was $11 \mathrm{~Bq} / \mathrm{m}^{-1} \mathrm{~s}^{-1}$ and 35 $\mathrm{Bq} / \mathrm{m}^{-1} \mathrm{~s}^{-1}$ for the lifting particles with diameters $d<10 \mu \mathrm{m}$ and $d<15 \mu \mathrm{m}$, respectively. During the same time period data on emission rate of soil particles with use of different kinds of machinery were obtained. These data are presented in Table 2.8 .

It has been shown in $/ 21 /$ that the particles emission rate is higher the mechanical resuspension rate by three orders of magnitude. It has also been noted that land band of $200 \mathrm{~m}$ between the zone of active mechanical working of soil and the rest of the area ensured a reduction in the air-born ${ }^{137} \mathrm{Cs}$ by two orders of magnitude. 

Soil particles emission rate with use of different kinds of machinery.

(Zapolie, 1993)

\begin{tabular}{||c|l|c|c||}
\hline \multicolumn{1}{|c|}{ Date } & \multicolumn{1}{|c|}{$\begin{array}{c}\text { Type } \\
\text { of vehicle }\end{array}$} & $\begin{array}{c}\text { Emission } \\
\text { rate, } \\
10^{-6} \mathrm{~s}^{-1}\end{array}$ & $\begin{array}{c}\text { Emission rate of } \\
\text { particles with } \\
d \leq 12 \mu \mathrm{m}, 10^{-6} \mathrm{~s}^{-1}\end{array}$ \\
\hline \hline $\begin{array}{l}12.05 .93 \text { morning } \\
13.05 .93 \text { morning }\end{array}$ & $\begin{array}{l}\text { İOZ-82 } \text { (tractor) } \\
\text { Ò-150 }-“-\end{array}$ & 0.027 & 0.004 \\
13.05 .93 afternoon & Ò-150 $-“-$ & 1.5 & 0.16 \\
22.05 .93 morning & ZIL-131 car & 1.0 & 0.20 \\
22.05 .93 afternoon & ZIL-131 - “- & 1.4 & 0.09 \\
24.05 .93 afternoon & ZIL-131 and ZIL-130 & 0.48 & 0.13 \\
\hline
\end{tabular}

2.4. Doses due to wind and mechanical resuspension of radioactive dust.

Estimates of doses due to mechanical resuspension of radioactive dust during agricultural works on the contaminated areas according to data of 1994 are presented in /21/. The inhalation dose received by a tractor driver in 832 hours of work per year has been estimated to be 0.07 $\mathrm{mSv}$ for lungs and the effective dose is $0.02 \mathrm{mSv}$.

The annual inhalation dose due to wind resuspension does not exceed $0.003 \mathrm{mSv} / 21 /$ for lungs and the effective dose is $0.0006 \mathrm{mSv}$.

The calculation of average effective dose due to wind resuspension received in 50 years in the area affected by radioactive contamination as a result of the accident at the Siberian chemical plant in Tomsk-7 on 06.04.93 suggests that the atmospheric contamination will be insignificant and does not pose any threat to the population. The density of soil contamination with gamma- and beta- irradiating radionuclides was $5 \mathrm{Ci} / \mathrm{km}^{2}$.

By the standards of radiation safety of Russian Federation there are no restrictions on living and anthropogenic activity in the area in which the annual effective dose does not exceed $1 \mathrm{~m} \mathrm{~Sv}$. So, the doses formed due to wind resuspension and mechanical resuspension do not present hazard for the population with time after the accident or at low level of soil contamination.

In conclusion of this section it should be said that since 1986 the works on wind resuspension rate $\alpha$ have been conducted on a regular basis.

By now the relationship between the wind resuspension rate and wind speed has been studied and analytical expressions to approximate this relationship have been derived. 
The relationship of wind resuspension rate on roughness length, vegetation height and amount of vegetation in the form of air-dried biomass matter has been established. Based on experimental data estimates of wind resuspension rate have been made.

The analysis of data obtained by different authors has shown that in 1986 the value of $\alpha$ was estimated at $(1 \div 10) 10^{-9} \mathrm{~s}^{-1}$ and in 1992 the values of $\alpha$ varied in the range $\left(1.1 \cdot 10^{-}\right.$ $\left.{ }^{13} \div 2.4 \cdot 10^{-10}\right) \mathrm{s}^{-1}$ with the exception of data of $/ 18 /$ where $\alpha(1.2 \div 1.5) 10^{-9} \mathrm{~s}^{-1}$ obtained in estimation of surface contamination density from ${ }^{137} \mathrm{Cs}$ content in the upper $1 \mathrm{~cm}$ soil layer.

It has been noted that the value of wind resuspension rate can vary by two orders of magnitude depending on the thickness of the upper soil from which the contamination density of the underlying surface is estimated.

The mean mechanical resuspension rate derived from data of 1994 corresponding to the situation in the population points Novozybkov, Mikulichi and Kovali is $1,4 \cdot 10^{-8} \mathrm{~s}^{-1}$ which is several orders of magnitude higher the wind resuspension rate. 


\section{References}

1. Healy J., Fuquay J. Wind pickup of radioactive particles from the ground. In: Proc. Second UN Conf. on the Peaceful Uses of Atomic Energy. Geneva, v.18, pp.291-295, 1951.

2. Anspaugh L.R., Shinn J.H., Phelps P.L., Kennedy N.C. Resuspension and redistribution of plutonium in soils. H1th. Phys., v.29, pp.571-582, 1975.

3. Shinn J.H., Homan D.N., Gay D.D. Plutonium aerosol fluxes and pulmonary exposure rates during resuspension from bare soils near a chemical separation facility. In Precipitation Scavenging, Day Deposition and Resuspension edited by Pruppacher H.R., Semonin R. G., Slinn W.G.H.) Vol 2, pp.1131-1143, Elsevier, Amsterdam.

4. Sehmel G.A. Particle resuspension: a review. Eniviron. Inter. V.4, pp.107-127, 1980.

5. Makhon'ko K.P., Rabotnova F.A. Resuspension and radioactive fallout from the soil surface and particulate contamination of vegetative cover. Pure Appl. Geophys., v.120, 11, 1982.

6. Makhonko K.P. Secondary entrance into the atmosphere of the dust deposited on the ground. Izvestia of USSR AS, FAO, v.15, 1 5, 1979.

7. Makhonko K.P. Estimation of parameters of wind entrainment of radioactive dust from ground surface . Izvestia of USSR AS, FAO, v.17, 17, 1981.

8. Makhonko K.P. Wind resuspension of radioactive dust from the underlying surface. Atomic energy, v.72, issue 5, 1992.

9. Garger E.K., Zhukov G.P., Sedunov Yu.S. About estimation of parameters of wind resuspension of radionuclides in the zone of the Chernobyl nuclear plant. Meteorology and hydrology, 11, 1990.

10. Garger E.K. Air concentration of radionuclides in the vicinity of Chernobyl and the effects of resuspension. J. Aerosol Sci. V.25, 15, 1994.

11. Naidenov A.V., Lukoyanov N.F. Experimental estimates of vertical fluxes and wind resuspension rates of radioactive dust above contaminated cultivated field. Collection of works of IEM, issue 57 (159) 1994.

12. Belyaev S.P., Surnin V.A. Estimation of wind resuspension of radioactive dust in Chernobyl in June 1986. Collection of works of IEM, issue 20(153) 1991.

13. Eco-Radiation monitoring of the surface air layer during natural and anthropogenic dust generation. Study and prediction of contamination under resuspension, transport and deposition of aerosol on local and meso-meteorological scale. Results of study of wind resuspension of radioactive dust in the Bryansk region in 1992. Report on R\&D. Contract 3 139/92-7/05,4-92-1. Obninsk, 1992.

14. Makhonko K.P. Resuspension of dust from the underlying surface covered by grass. Meteorology and hydrology, 110, 1986. 
15. Transuranium elements in the environment. Ed by U.S.Khenson, M. Energoatomizdat, 1985.

16. Nicholson K.W. Review of particle resuspension. Atmos. Environ. V.22, 112, 1988.

17. Gavrilov V.P., Klepikova N.V., Troyanova N.I., Makhon'ko K.P. Determination of wind re-suspension rate of radionuclides and assessment of radioactivity in the atmospheric air in Bryansk region. Radiation Protection Dosimetry., V.64, 1 1/2, 1996.

18. Naidenov A.V., Lukoyanov N.F. Experimental estimation of vertical fluxes and wind resuspension rate of radioactive dust above cultivated field. Collection of works of IEM, issue 57 (159), 1994.

19. Gavrilov V.P., Klepikova N.V., Troyanova N.I. Stationary model for resuspension of radionuclides and assessment of ${ }^{137} \mathrm{Cs}$ concentration in the near-surface layer for the contaminated areas in the Bryansk region of Russia and Belarus. Atmos. Envir., v.29, 119, 1995.

20. Voszhennikov O.I. Estimation of parameters of wind resuspension. Collection of works of IEM, issue 57 (159), 1994.

21. Hallander W., Garger E. Contamination of surfaces by resuspended material. Final report. Published by the European commission. Luxembourg, 1996.

22. Garger E. et al. Resuspension and deposition of radionuclides under various conditions. In: The radiological consequences of the Nornobyl accident. Proceedings of the First international conference. Minsk, Belarus, 18-22 March, 1996. Luxembourg, 1996.

23. Rusakov Yu.S.Makhonko K.P. Study of air contamination by radioactive dust in the territory of the Bryansk region. Meteorology and hydrology, 17, 1996. 


\section{Mass load.}

When estimating the concentration of a contaminant in the air through determination of mass load detailed characteristics of soil during wind resuspension can be ignored and relation can be established between measurements of contaminant concentration in soil and air by the concentration of soil particles in the air. That is to say, the contaminant concentration in the air is expressed as a product of its concentration in the soil and concentration of soil particles in the air. If the number of soil particles in the air is known from some considerations, then theoretically for estimating contaminant concentration in the air, it is enough to measure concentration of contaminants in the soil. In a general case this can be written as

$$
q=A_{s} \cdot C_{d},
$$

where $q$ is concentration of contaminants in the air, $A_{s}$ is specific concentration of contaminants in the upper soil layer, $C_{d}$ is dust concentration in the air.

For such estimation two parameters are required: dust concentration in the atmosphere and contaminant concentration in the soil. By data obtained in UK in 1966 from the national air monitoring network, the average dust concentrations for urban stations are in the range 33-254 $\mu \mathrm{g} / \mathrm{m}^{3}$ and for rural $-9-79 \mu \mathrm{g} / \mathrm{m}^{3} / 5 /$. By the data of the national service of atmospheric monitoring the background air contamination levels /1, 2/ and air contamination levels averaged over a year for cities of the former USSR $/ 3 /$ are $0.02-0,03 \mathrm{mg} / \mathrm{m}^{3}$ and $0.20 \mathrm{mg} / \mathrm{m}^{3}$, respectively.

By data of /4/ obtained in July-August 1992 in the vicinity of Novozybkov the dust concentration varied from 30 to $170 \mu \mathrm{g} / \mathrm{m}^{3}$ and the average value was equal to $95 \mu \mathrm{g} / \mathrm{m}^{3}$.

The verification of the mass load method was conducted in $/ 5 /$. Concentrations of some radionuclides in the air were measured and compared to concentrations calculated by the radionuclides concentration in the soil under the assumption of the air dust concentration of 100 $\mu \mathrm{g} / \mathrm{m}^{3}$. The results of comparison have shown the workability of the method. In $/ 4 /$ the experimental values of ${ }^{137} \mathrm{Cs}$ concentration in the air above a cultivated field at the height $1.3 \mathrm{~m}$ (July-August 1992 in the vicinity of Novozybkov) were compared to the values calculated from measurements in the same period for counting dust concentrations in the air and specific activity of soil fractions. It has been estimated that the average over this period value of experimental concentrations is higher the average calculated concentrations of ${ }^{137} \mathrm{Cs}$ in the air by a factor of 1.4 , which suggests that the method can be successfully used.

The difficulties in using the mass load method are related to estimation of dust concentration in the air. It should be noted that using data of air monitoring network can bring 
in some uncertainties associated with the fact that the collected particles may include part of particles of industrial origin and therefore the results may be overestimation. Besides, samplers are not always placed in the zones of human inhalation.

Another issue is the dust origin. Fine particles in the air can be transported over long distances and as most of the contaminated areas are rather limited in size it can be assumed that only part of the dust originates from these areas and hence, the background dust can be assumed to be uncontaminated and finely-dispersed, i.e. the large particles deposit in the vicinity of the dust-forming source.

An important point is contaminant concentration in the soil. Soil particles entrained in resuspension have a small size, while the large ones deposit quickly. Therefore, if the concentration of contaminant in the soil fraction containing fine particles differs considerably from the concentration in other size fractions, then a low concentration can be expected which is predicted by mass load using the total soil concentration. In $/ 2 /$ it was proposed to use the enrichment coefficient defined as a sum of products of $q$ which are the ratio of proportion of total activity in the increment of the $i$-th size and the total mass of this fraction and $f$-proportion of mass of each increment of aerosol particle size. For soil particles with known distribution $/ 5 /$ the calculated enrichment coefficient is 1.5 . 


\section{References}

1. Izrael Yu.A., Nazarov I.M. et al Acid rains, L. Hydrometeoizdat, 1983, 206 p.

2. Review of background state of the environment in the territory of Russia in 1992 Ed by Yu. A.Izrael and F.Ya.Rovinsky. M.: Moscow dep. Hydrometeoizdat, 1993, 44 p.

3. Bezuglaya E.Yu., Rastorgueva G.N., Smirnova I.V. What an industrial city breathes with. L. Hydrometeoizdat, 1991, 255 p.

4. Naidenov A.V., Lukoyanov N.F., Meshkova V.G. Estimation of ${ }^{137}$ Cs contamination of the surface air and its distribution in the soil and air above cultivated field. Collection of works of IEM, issue 57 (159), 1994.

5. Transuranium elements in the environment, Ed by U.S.Henson. M.: Energoizdat, 1985, $344 \mathrm{p}$.

6. Tumura T.Plutonium association in soils, in transuranics in natural environments. Symposium proceedings, Gatlinburg, Oct, 5-7, 1976 


\section{Calculation formulae for characteristics of wind resuspension of radioactive dust.}

\subsection{Formulae to calculate resuspension wind and resuspension factor.}

The analysis of the available data on resuspension characteristics has shown that data are available and approximations have been derived for dependence of resuspension rate on wind speed /1, 2, 3/, roughness length, height of grass cover and bush and phytomass /4/. Yet, resuspension rate has not been related to time in case of a long term period, i.e. for intervals more than 3 years, while for the wind resuspension factor there are many time-dependent approximations, but the dependence on other parameters has not been studied. It should be noted in this respect that all of the derived dependencies are empirical in character.

Therefore, we consider both the resuspension rate and resuspension factor and first establish the relation between these two characteristics. To pass from $\alpha$ to $R$ we use the notion of characteristic rate in the near-surface layer $\bar{u}$,

$$
\alpha=\bar{u} R
$$

or the effective rate of radioactive dust resuspension from the underlying surface $v_{\alpha} / 6 /$

$$
\alpha=v_{\alpha} \cdot R
$$

For the climatic conditions characteristic of the central part of Russia the effective rate is $2 \div 5 \mathrm{~cm} / \mathrm{s}$, for the nuclear testing ground in Nevada (USA) $v_{\alpha}=5 \mathrm{~cm} / \mathrm{s} / 6 /$.

We use the approach to establishing the relation between the two characteristics of wind resuspension $R$ and $\alpha$ proposed in /7, 8/. According to the Monin-Obukhov theory the expression for the difference in concentrations in the thermally stratified near-surface atmospheric layer is written as

$$
q\left(z_{2}\right)-q\left(z_{1}\right)=\frac{Q}{x_{1} u_{*}}\left[\ln \frac{z_{2}}{z_{1}}-\Phi\left(\frac{z_{2}}{L}\right)+\Phi\left(\frac{z_{1}}{L}\right)\right],
$$

where $q$ is radionuclide concentration in the air;

$Q$ is vertical flux of radionuclides;

$u$ is friction velocity;

$L$ is the Monin Obukhov length scale of the atmospheric stability;

$\Phi\left(\frac{z}{L}\right)$ are universal similarity functions in the Monin-Obukhov theory; 
$\dddot{1}_{1}=æ / \operatorname{Pr} ;$

$æ=0.4$ is the von Karman constant;

$\operatorname{Pr}=0.85$ is Prandtle number;

$z_{1}, z_{2}$ are fixed heights in the atmospheric surface layer.

Formula (4.1) is the basis for using the gradient method mentioned above.

If as $z_{2}$ we take the height $\delta$ at which $q(\delta)=0$, then

$$
\mathrm{q}=\frac{\mathrm{Q}}{\mathfrak{x}_{1} \mathrm{u}_{*}}\left[\ln \frac{\delta}{\mathrm{z}_{1}}-\Phi\left(\frac{\delta}{\mathrm{L}}\right)+\Phi\left(\frac{\mathrm{z}_{1}}{\mathrm{~L}}\right)\right],
$$

If for some considerations the value of $\delta$ is known then assuming $Q_{a}=\alpha C$ we get

$$
\alpha=\frac{æ_{1} u_{.} R}{\left[\ln \frac{\delta}{z_{1}}-\Phi\left(\frac{\delta}{L}\right)+\Phi\left(\frac{z_{1}}{L}\right)\right]} .
$$

As the height $\delta$ as shown in /8/ we can take the surface layer height $H$, then

$$
\alpha=\frac{æ_{1} u_{.} R}{\left[\ln \frac{H}{Z_{1}}-\Phi\left(\frac{H}{L}\right)+\Phi\left(\frac{Z_{1}}{L}\right)\right]},
$$

or

where

$$
R=f\left(H, z_{1}\right) \cdot \alpha
$$

$$
f\left(H, z_{1}\right)=\frac{\left[\ln \frac{H}{z_{1}}-\Phi\left(\frac{H}{L}\right)+\Phi\left(\frac{z_{1}}{L}\right)\right]}{æ_{1} u_{*}} .
$$

Considering that the experimental data have been obtained in the conditions close to neutral stratification, we get

$$
f\left(H, z_{1}\right)=\ln \left(H / z_{1}\right) / u_{*} .
$$

The measurements used for determining of resuspension characteristics are carried out at different heights from the underlying surface. Therefore, it is useful to introduce the height averaged resuspension factor as 


$$
\bar{R}=R(z) / \ln \delta / z
$$

or

$$
\bar{R}=R(z) / \ln H / z
$$

Then,

$$
\alpha=\bar{R} \cdot æ_{1} u_{.}
$$

Using $\bar{R}$ for interpretation of measurements is preferable, as this factor does not depend on measurement height and hence is a more universal characteristic. Further, the consideration is based on the assumption that the wind speed is measured at the vane height $(9 \mathrm{~m})$, unless it is specified otherwise.

As noted above, that there are approximations for dependencies of resuspension rate on wind speed. These expressions, however, have been derived either for non-osculating speed intervals /1, 2/ or at the bounds of speed intervals resuspension rates change jumpwise /3/.

Analysing the available experimental data derived at different wind speeds and using the approximation formulae, two expressions for dependency of resuspension rate on wind speed have been derived

$$
\begin{aligned}
& \alpha=7,7 \cdot 10^{-9} u^{2,25}, \\
& \alpha=10^{-11} u^{2}\left(0,012 u^{3}-0,65 u+8,0\right),
\end{aligned}
$$

for $0 \leq u \leq 15 \mathrm{~m} / \mathrm{s}$.

Expressions (4.10), (4.11) combine the approximations derived earlier. Formula (4.10) is rather simple, but describes the available experimental data satisfactorily.

We will be using these two expressions. The values of $\alpha$ calculated by (4.10) and (4.11) are shown in Fig 4.1.

The expressions for $\bar{R}$ and $R$ take the form

$$
\begin{gathered}
\bar{R}=\alpha /\left(æ_{1} \cdot u_{.}\right), \\
R=\frac{\alpha \cdot \ln H / z}{æ_{1} u_{.}} .
\end{gathered}
$$

Assuming that the dependence $R$ on time is written as (1.11), considering (4.10), (4.11) and substituting data $æ_{1}=0,47, \quad u .=c_{d}^{1 / 2} \cdot u, \quad c_{d}^{1 / 2}=0,07$, we get

$$
\begin{aligned}
& R=5,3 \cdot 10^{-5} u^{1,25} t^{-1,67} \\
& R=1,1 \cdot 10^{-5} t^{-1,67} u\left(0,012 u^{3}-0,65 u+8,0\right)
\end{aligned}
$$


where $t$ is time after the accident in days. The expressions for resuspension rate will then be written as

$$
\begin{aligned}
& \alpha=5,1 \cdot 10^{-7} u^{2,25} t^{-1,67} . \\
& \alpha=1,05 \cdot 10^{-7} t^{-1,67} u^{2}\left(0,012 u^{3}-0,65 u+8,0\right)
\end{aligned}
$$

Expression (1.11) has been chosen for describing the dependence of the resuspension factor on time because it has been derived with a fairly large volume of experimental data obtained in Chernobyl during a long observational period (more than 4 years) and in Haunover during 1222 days after the accident.

For deriving the dependence of wind resuspension rate on the underlying surface characteristic such as roughness length works /1, 2, 4/ were analysed. In /4/ the dependence of $\alpha$ on $z_{0}$ has been obtained, the wind speeds varying in the range $2 \div 6 \mathrm{~m} / \mathrm{s}$. The data show that for wind speed in this range the relation between $\alpha$ and $z_{0}$ in the bilogarythmic scale is satisfactorily described by a straight line. Since the slope angle of this line is weakly dependent on the wind speed it can be assumed that such a dependence of $\alpha$ on $z_{0}$ is valid for a wider range of wind speeds. Taking into account that the experimental data $/ 1,2 /$ have been derived for $z_{0}=3,4 \mathrm{~cm}$ and the relation $\alpha$ and $z_{0}$ is established for mean monthly wind speeds $2 \div 6 \mathrm{~m} / \mathrm{s}$ at height $10 \mathrm{~m}$ and assuming that all the data have been obtained in the atmospheric conditions close to neutral stratification, we get

$$
\begin{gathered}
R=\frac{2,8 \cdot 10^{4} u^{1,25} t^{-1,67}}{z_{0}^{1,4}}, \\
a=\frac{2,7 \cdot 10^{6} u^{2,25} t^{-1,67}}{z_{0}^{1,4}}, \\
R=\frac{6,1 \cdot 10^{-5} t^{-1,67} u\left(0,12 u^{3}-0,65 u+8,0\right)}{z_{0}^{1,4}}, \\
\alpha=\frac{5,9 \cdot 10^{-7} t^{1,67} u^{2}\left(0,12 u^{3}-0,65 u+8,0\right)}{z_{0}^{1,4}}
\end{gathered}
$$

where $z_{0}$ is given in $\mathrm{cm}$.

For the water surface $R, \alpha=0$ as the water surface is absorbing and radionuclides can be resuspended to the atmosphere only due to evaporation.

In the winter time when the soil is covered with snow no dust resuspension from the soil surface occurs, and therefore, $R, \alpha$ can be taken to be 0 . 
For the territories covered by forest there are few data on resuspension rate. It is known $/ 3$, $9,10 /$ that $\alpha$ for forest, given fresh depositions of radionuclides, is $2 \div 9$ times higher the resuspension rate for radioactive dust from the field. Results of numerical experiments, the starting data for which were observations of 1992-93 in Novozybkov, suggest that the resuspension rate $\alpha$ for forest is lower the corresponding $\alpha$ for meadow and arable land. Thus, in (4.12)-(4.15) in calculation of the averaged resuspension factor and resuspension rate $R, \alpha$ the empirical coefficient $K_{f}$ is introduced for forest. As the comparison with experimental data has shown

$$
\hat{E}_{f}=\left\{\begin{array}{l}
5, \text { for the first year after the accident and forest as underlying surface; } \\
1, \text { for subsequent years and other types of underlying surfaces in the first year. }
\end{array}\right.
$$

The dependence of resuspension rate on moisture content of the upper soil layer has been already discussed above. This dependence can be taken into account by introducing a dimensionless factor $K_{m}$ in (4.13). The dependence of this factor on the moisture content in the upper soil layer was obtained by analysis of field experiment /11/ and expert judgements /13/. Table 4.1 includes the values of $K_{m}$ factor as a function of quality (visual) evaluation of moisture content of the upper soil layer using methodology /12/.

Table 4.1

\begin{tabular}{||c|c|c|c||}
\hline $\begin{array}{c}\text { Soil } \\
\text { moisture } \\
\text { class }\end{array}$ & $\begin{array}{c}\text { Quality characterization of moisture } \\
\text { in the upper soil layer }\end{array}$ & $\begin{array}{c}\text { Soil-hydrological } \\
\text { constant }\end{array}$ & $\begin{array}{c}\text { Factor } \\
\text { value } K_{m}\end{array}$ \\
\hline \hline 1,2 & $\begin{array}{c}\text { wet soil, puddles, surface layer } \\
\text { is flowing or sticky }\end{array}$ & saturated soil & 0.13 \\
\hline 3 & very moistened soil, soft & $\begin{array}{c}\text { field specific } \\
\text { retention }\end{array}$ & 0.26 \\
\hline 4 & weakly moistened soil, hard & $\begin{array}{c}\text { wilting point } \\
\text { content }\end{array}$ & 1 \\
\hline 5 & dry soil, loose & maximum \\
hydroscopisity & \\
\hline
\end{tabular}

The quality characterization of moisture content in the upper soil layer may be related to soil-hydrological constants. Table 4.1 shows the relation between the soil moisture classes and soil hydrological constants.

Coefficient $K_{m}$ is incorporated in (4.12), (4.13) as a factor, as is the empirical coefficient $K_{f}$. 
The anthropogenic activity influences the concentration of mineral dust in the air as well as radionuclides. In /2, 10, 13/ empirical coefficients for increase in radioactive dust concentration in the air due to anthropogenic and agricultural activities have been derived. Considering that the experimental data used for deriving the resuspension rate and resuspension factor have been obtained in field, meadow or forest where anthropogenic activity is insignificant, if any, and combining the data of $/ 11,12 /$ we get the values of anthropogenic coefficient $K_{a}$ : on working days $K_{a}=1.3$ for settlements and cities; $K_{a}=1$ on weekend. $K_{a}$ is included in (4.12) and (4.13) as a factor. It should be noted that here we do not include field agricultural works in anthropogenic activity and this will be considered separately.

We shall consider two other types of underlying surface: bog and soil partly covered with snow. In the first case, the radionuclide resuspension can occur from vegetation and hillocks. To estimate wind resuspension from the surface which is not dust-forming partially, the coefficient $K_{w}=S_{r} / S_{t}$ where $S_{r} / S_{t}$ is ratio of areas of dust-forming and entire area.

So, based on the introduced factors, the resuspension factor and resuspension rate will take the form:

$$
\begin{gathered}
R=\frac{2,9 \cdot 10^{4} u^{1,25} t^{-1,67} K_{f} \cdot K_{m} \cdot K_{a}\left(1-K_{w}\right)}{z_{o}^{1,4}}, \\
\alpha=\frac{2,8 \cdot 10^{-6} u^{2,25} t^{-1,67} K_{f} \cdot K_{m} \cdot K_{a} \cdot\left(1-K_{w}\right)}{z_{0}^{1,4}} \\
R=\frac{6,1 \cdot 10^{-5} t^{-1,67} u\left(0,12 u^{3}-0,65 u+8,0\right) K_{f} \cdot K_{m} \cdot K_{a} \cdot\left(1-K_{w}\right)}{Z_{o}^{1,4}} \\
\alpha=\frac{5,8 \cdot 10^{-7} t^{-1,67} u^{2}\left(0,12 u^{3}-0,65 u+8,0\right) K_{f} \cdot K_{m} \cdot K_{a} \cdot\left(1-K_{w}\right)}{z_{0}^{1,4}}
\end{gathered}
$$

In (4.16)-(4.19) $t$ is time since the accident in days.

\subsection{Estimation of mechanical resuspension rate.}

This section deals with description of areas of field agricultural works. As mentioned in 2.3 , the radius of the zone is about $\sim 200 \mathrm{~m}$, and the ground band of approximately the same width serves to reduce the radionuclide concentration in the air by a factor of 2 .

To estimate the mechanical resuspension, data of $/ 9,10 /$ are used. Summarizing results presented in these works we get that the rate of mechanical resuspension of particles $\alpha_{m}$ of all sizes $\sim(1.5 \pm 0.6) \cdot 10^{-8} \mathrm{~s}^{-1}$. Considering the data of Table 2.7 this value rather applies to wind resuspension of particles with diameter more than $15 \mu \mathrm{m}$. Estimation of rate of mechanical 
resuspension of respirable particles of smaller diameter $(\mathrm{d}<12 \mu \mathrm{m})$ by their emission rate from soil has shown that $\alpha_{m} \approx 0.11 \cdot 10^{-9} \mathrm{~s}^{-1}$. For some kinds of agricultural machinery the mechanical resuspension rate was estimated by data of /9/ and the derived data are presented in Table 4.2. 
Mechanical resuspension rate with operation of some kinds of machinery

\begin{tabular}{||c|c|c||}
\hline \multirow{2}{*}{ Kind of machinery } & \multicolumn{2}{|c|}{ Mechanical resuspension rate $\alpha_{m}, 10^{-9} \mathrm{~s}^{-1}$} \\
\cline { 2 - 3 } & particles with $d>12 \mu \mathrm{m}$ & particles with $d<12 \mu \mathrm{m}$ \\
\hline Tractor MTZ-82 & 0,03 & 0,004 \\
Tractor T-150 & 1,8 & 0,18 \\
Vehicle ZIL-131 & 1,2 & 0,11 \\
\hline
\end{tabular}

\subsection{Comparison of calculated values $\alpha$ and $R$ with experimental.}

For comparison we take published experimental data. The main criterion for selection of data was availability of description of natural-climatic conditions of an experiment: wind speed, type of underlying surface, height and location of obstruction and soil moisture. The experiments on determination of parameters of wind resuspension of radioactive dust are usually conducted under conditions of neutral stratification of the atmosphere or close to them and therefore, it was assumed in the calculations that the profile of wind speed changes with height by the logarithmic law.

The resuspension factors $R$ were calculated by (4.16) and (4.18) for time 15,117 days after the accident for September 1987-1991 and end May 1992. The wind speed and roughness length were taken to be equal to averaged-climatic values $3 \mathrm{~m} / \mathrm{s}$ and $3.4 \mathrm{~cm}$, respectively. The calculations were compared to experimental $/ 8,9 /$ averaged over separate years. As the calculations by (4.16) and (4.18) are close (see Table 4.3 ) fig.4.2 shows only one calculated curve derived by (4.16). Table 4.3 shows all resuspension factors $R$ calculated by $(4.16),(4,18)$ and corresponding experimental results $/ 8,9 /$. The presented data show that the calculated and experimental values of $R$ are in good agreement; the correlation factor estimated with these data is 0.9 .

Table 4.4 includes starting data for calculations of resuspension rate $\alpha$, the date of measurements, characteristics of the underlying surface, wind speed and height at which it was measured, source of information. The dashes in the table mean that the data are not available. These data were used to estimate parameters required for calculating resuspension rate $\alpha$ with formulae (4.17), (4.19). Table 4.5 includes the values of parameters, resuspension rates $\alpha$ calculated by (4.17) and (4.19) and those received empirically by the authors of works indicated in Table 4.4. 
Table 4.3

Calculated and experimental wind resuspension factors $R, \mathrm{~s}^{-1}$

\begin{tabular}{||c|c|c|c||}
\hline $\begin{array}{c}\text { Time after accident } \\
\text { day }\end{array}$ & $\begin{array}{c}R, \mathrm{~s}^{-1} \\
(4.16)\end{array}$ & $\begin{array}{c}R, \mathrm{~s}^{-1} \\
(4.18)\end{array}$ & $\begin{array}{c}R, \mathrm{~s}-1 \\
/ 9 /\end{array}$ \\
\hline \hline 15,0 & $0,216 \cdot 10^{-5}$ & $0,228 \cdot 10^{-5}$ & $3,0 \cdot 10^{-6}$ \\
117,0 & $0,701 \cdot 10^{-7}$ & $0,739 \cdot 10^{-7}$ & $3,3 \cdot 10^{-8}$ \\
482,0 & $0,659 \cdot 10^{-8}$ & $0,695 \cdot 10^{-8}$ & $8,2 \cdot 10^{-9}$ \\
847,0 & $0,257 \cdot 10^{-8}$ & $0,271 \cdot 10^{-8}$ & $3,2 \cdot 10^{-9}$ \\
1212,0 & $0,141 \cdot 10^{-8}$ & $0,149 \cdot 10^{-8}$ & $1,4 \cdot 10^{-9}$ \\
1577,0 & $0,910 \cdot 10^{-9}$ & $0,960 \cdot 10^{-9}$ & $6,0 \cdot 10^{-10}$ \\
1942,0 & $0,643 \cdot 10^{-9}$ & $0,678 \cdot 10^{-9}$ & $8,0 \cdot 10^{-10}$ \\
\hline
\end{tabular}


Table 4.5

Resuspension rate $\alpha$ calculated by (4.17) and (4.18) and calculation parameters

\begin{tabular}{|c|c|c|c|c|c|c|c|}
\hline 1 & $\begin{array}{c}\text { Time } \\
\text { since } \\
\text { accident } \\
\end{array}$ & $\begin{array}{l}\text { Roughness } \\
\text { length }\end{array}$ & $\hat{E}_{m}$ & $\hat{E}_{f}$ & $\begin{array}{c}\text { Wind speed } \\
\text { at } 9 \mathrm{~m} \\
\mathrm{~m} / \mathrm{s} \\
\end{array}$ & $\begin{array}{c}\alpha, \mathrm{s}^{-1} \\
\text { by }(4.17),(4.18)\end{array}$ & $\begin{array}{c}\alpha_{\text {exp }} \\
\mathrm{s}^{-1} \\
\text { source }\end{array}$ \\
\hline 1.1 & 30 & 7 & $\overline{0,52}$ & 1 & 3,8 & $6,36 \cdot 10^{-9}, \quad 6,14 \cdot 10^{-9}$ & $10^{-8} / 15 /$ \\
\hline 1.2 & 32 & 7 & 1 & 1 & 3,8 & $1,10 \cdot 10^{-8}, \quad 1,06 \cdot 10^{-8}$ & $4 \cdot 10^{-8} / 15 /$ \\
\hline 2.1 & 157 & 2 & 1 & 1 & 3,9 & $4,72 \cdot 10^{-9}, \quad 4,52 \cdot 10^{-9}$ & $1,0 \cdot 10^{-9} \quad / 9 /$ \\
\hline 2.2 & 157 & 0,6 & 0,52 & 1 & 3,6 & $1,11 \cdot 10^{-8}, \quad 1,09 \cdot 10^{-8}$ & $2,1 \cdot 10^{-9} \quad / 9 /$ \\
\hline 2.3 & 157 & 50 & 1 & 5 & 10,4 & $2,37 \cdot 10^{-9}, 4,23 \cdot 10^{-9}$ & $3,7 \cdot 10^{-9} \quad / 9 /$ \\
\hline 3.1 & 1855 & 0,7 & 1 & 1 & 2 & $7,39 \cdot 10^{-11}, 9,20 \cdot 10^{-11}$ & $1,0 \cdot 10^{-10} / 8 /$ \\
\hline 3.2 & 1860 & 2,4 & 0,52 & 1 & 3 & $1,70 \cdot 10^{-11}, 1,79 \cdot 10^{-}$ & $1,4 \cdot 10^{-11} / 8 /$ \\
\hline $3,2,1$ & 1865 & 3 & 1 & 1 & 2 & $\begin{array}{l}9,55 \cdot 10^{-12}, 1,19 \cdot 10^{-} \\
11\end{array}$ & $3,3 \cdot 10^{-11} / 8 /$ \\
\hline 4 & 2240 & 5 & 1 & 1 & 3,4 & $1,13 \cdot 10^{-11}, 1,14 \cdot 10^{-}$ & $7,8 \cdot 10^{-11} / 16 /$ \\
\hline
\end{tabular}


Table 4.4.

Starting data for calculating the resuspension rate

\begin{tabular}{|c|c|c|c|c|c|c|c|}
\hline 1 & $\begin{array}{l}\text { Underlying } \\
\text { surface }\end{array}$ & $\begin{array}{c}\text { Obstruction } \\
\text { height } \\
\text { and location }\end{array}$ & $\begin{array}{c}\text { Experiment } \\
\text { date }\end{array}$ & $\begin{array}{c}\text { Soil } \\
\text { moisture }\end{array}$ & Wind speed & $\begin{array}{c}\text { Wind speed } \\
\text { measurement } \\
\text { height }\end{array}$ & Authors \\
\hline 1.1. & $\begin{array}{l}200 \mathrm{~m} \text { - field } \\
\text { covered by grass } \\
100 \mathrm{~m} \text { - bush, } \\
\text { structures }\end{array}$ & $\begin{array}{c}30-40 \mathrm{~cm}, \\
\text { sparse } \\
\text { individual }\end{array}$ & 11.06 .86 & wet & $2,1 \mathrm{~m} / \mathrm{s}$ & $1 \mathrm{~m}$ & $\begin{array}{c}\text { Belyaev S.P. } \\
\text { Surnin V.A. } \\
/ 15 /\end{array}$ \\
\hline 1.2. & $\begin{array}{l}200 \mathrm{~m} \text { - field } \\
\text { covered by grass } \\
100 \mathrm{~m} \text { - bush, } \\
\text { structures }\end{array}$ & $\begin{array}{c}30-40 \mathrm{~cm}, \\
\text { sparse } \\
\text { individual }\end{array}$ & 13.06 .86 & dry & $2,1 \mathrm{~m} / \mathrm{s}$ & $1 \mathrm{~m}$ & \\
\hline 2.1 . & Cultivated field & - & & - & & & $\begin{array}{l}\text { Hallander W. } \\
\text { Garger E. } \\
\text { /9/ }\end{array}$ \\
\hline 2.2 & Beach Pripyat & - & & - & & & \\
\hline 2.3 . & Young pine forest & $5-6 \grave{1}$ & $\begin{array}{l}\text { September - } \\
\text { october } 1986\end{array}$ & - & $2,5 \mathrm{~m} / \mathrm{s}$ & $1 \mathrm{~m}$ & \\
\hline 3.1 . & Meadow arable land & - & $\begin{array}{c}22-27 \\
\text { May } 1992\end{array}$ & dry & $1-2 \mathrm{~m} / \mathrm{s}$ & $9 \mathrm{~m}$ & $\begin{array}{l}\text { Voszhennikov } \\
\text { O.I. }\end{array}$ \\
\hline 3.2. & Meadow arable land & - & $\begin{array}{c}1-10 \\
\text { June } 1992\end{array}$ & wet & & & \\
\hline 4. & Rye field & & $\begin{array}{c}\text { July-august } \\
1992\end{array}$ & dry & $2,9 \mathrm{~m} / \mathrm{s}$ & $4 \mathrm{~m}$ & 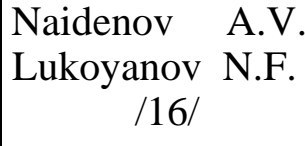 \\
\hline
\end{tabular}


Results derived with (4.17), (4.19) and experimental data /13, 15-17/ are also presented in Fig 4.3. The experimental data are along the abscissa axis and results calculated by (4.17) and (4.19) are along the ordinate axis. The distance of signs from the regression line (the signs represent calculations) show the deviation of the experimental data from the calculated ones. The analysis of data of Tables 4.5 and 4.3 shows that formulae (4.17), (4.19) satisfactorily approximate the experimental data. The greatest deviation (almost an order of magnitude) occurs in the resuspension rate for the Pripyat river bank (2.2 Table 4.5). This difference is caused by the difference in the value of roughness length $z_{0}=0.6 \mathrm{~cm}$ in the calculations and $z_{0}=2 \div 6 \mathrm{~cm}$ in $/ 9 /$.

Returning to the initial data used for deriving approximation expressions, it should be pointed out that the resuspension rate $\alpha$ at large wind speeds $u$ was earlier found to be proportional to $u^{5}$. Therefore, expressions (4.18), (4.19) are recommended to be used at large wind speeds and roughness length and in other cases - (4.16) and (4.17).

In conclusion of this section let us summarize the main results:

- formulae for the resuspension factor and resuspension rate have been derived including the dependence of these parameters on time since the accident, wind speed, roughness length, type of the underlying surface, moisture content of the soil and intensity of anthropogenic activity;

- the values of mechanical resuspension rate for a general case and when operating machinery have been presented;

- the comparison of resuspension rates derived by (4.16)-(4.19) and experimental measurements shows good agreement between the data;

- the correlation factor for calculated and experimental data for the wind resuspension is 0,9;

- it is recommended that for calculating the resuspension factor and resuspension rate formulae (4.18) and (4.19) are used at large wind speeds and roughness length, while in other cases (4.16) and (4.17) should be used. 


\section{References}

1. Nicholson K.W. Review of particle resuspension Atmos.Environ. V.22 112, 1988.

2. Transuranium elements in the environment ED. by Y.S.Henson Energoatomisdat, 1985.

3. Gavrilov V.P., Klepikova N.V., Troyanova N.I., Makhon'ko K.P. Determination of wind resuspension rate of radionuclides and assessment of radioactivity in the atmospheric air in the Bryansk region. Radiation protection Dosimetry, V.64, 11/2, 1996.

4. Makhonko K.P. Wind resuspension of dust from the underlying surface covered with grass. Meteorology and hydrology. 110, 1986.

5. Buikov M.V. About wind resuspension of aerosol particles, Meteorology and hydrology, 16, 1992.

6. Makhonko K.P. About effective rate of resuspension of dust from the underlying surface. Meteorology and hydrology 15, 1991

7. Vozshennikov O.I., Burkov A.I., Quasihomogeneous model for calculating turbulent fluxes of matter from the underlying surface. Meteorology and hydrology, 15, 1991.

8. Vozshennikov O.I. Estimation of resuspension parameters. Collection of works of IEM, issue 57 (159), 1994.

9. Hallander W., Garger E., Contamination of surfaces by resuspended material. Final report. Published by the European Commission Luxemburg, 1996.

10. Garger E. et al. Resuspension and deposition of radionuclides under various conditions. In: The radiological consequences of the Chernobyl accident. Proceedings of the first international conference. Minsk Belarus, 18-22 March 1996. Luxemburg, 1996.

11. Rusakov YU.S., Makhon'ko K.P. Study of the air contamination by radioactive dust in the territory of the Bryansk region Meteorology and hydrology 17, 1996.

12. Guidelines for hydrometeorological stations and posts, Issue 11. Agrometeorological observations at stations and posts. L. Hydrometeoizdat, 1973.

13. Radiation-environmental monitoring of the surface atmospheric layer under natural and technological dust-formation. Study and prediction of the contamination under resuspension, transport and deposition of aerosol on a local and mesometeorological scale. Results of study of wind resuspension of radioactive dust in the Bryansk region in 1992. Report on R\&D, Contract 1139/92-7/05.4-92-1. Obninsk, 1992.

14. Bratsert U.H. Evaporation to the atmosphere. Theory, history, applications TRAnslated from English Ed. by A.S.Dubov, L.Hydromeeoizdat, 1985.

15. Belyaev S.P., Surnin V.A.Estimation of wind resuspension of radioactive dust in Chernobyl in June 1986. Collection of works of IEM, issue 20(153), 1991. 
16. Garger E.K., Zhukov G.P., Sedunov Yu.S. On estimation of parameters of resuspension of radionuclides in the area of the Chernobyl nuclear power plant. Meteorology and hydrology, 11, 1990.

17. Naidenov A.V., Lukoyanov N.F. Experimental estimation of vertical fluxes and resuspension rates of radioactive dust above contaminated cultivated field. Collection of works of IEM, issue 57(159), 1994. 


\section{Methodology for estimating the resuspension rate and resuspension factor and} the flux of radioactive dust from the underlying surface.

\subsection{Input parameters required for calculation.}

For calculation of resuspension rate and resuspension factor from the underlying surface the following data are required:

$t$, days is time in days since the accident;

$u, \mathrm{~m} / \mathrm{s}$ is wind speed measured at $10 \mathrm{~m}$ height or recalculated for this height;

$z_{0}, \mathrm{~cm}$ is roughness length;

$h$, $\mathrm{cm}$ is height of obstructions;

$K_{m}$ is characteristic of soil moisture content;

$K_{f}$ is characteristic of the underlying surface (water surface, forest etc.);

$K_{w}$ is a part of the area under water, snow;

$K_{a}$ is the coefficient of anthropogenic activity;

$A, \mathrm{~Bq} / \mathrm{cm}^{2}$ is density of radioactive contamination of the underlying surface;

$H$ is height of the surface layer;

\subsection{Roughness length.}

Roughness is an important parameter in deriving the speed profile. The roughness length is usually designated by $z_{0}$. The relation between the roughness length and measured characteristics of obstructions is the subject of many studies. For example, work /4/ presents relations of roughness length $z_{0}$ and the average height of roughness components $h_{0}$

$$
\left(h_{0} / z_{0}\right)=e^{2} \approx 7,39
$$

for widely spaced obstructions and

$$
\left(h_{0} / z_{0}\right)=3 e \approx 8,15
$$

for closely spaced obstructions.

The values $z_{0} / 1,2 /$ for most frequently occurring surfaces are shown in Table 5.1. 
Table 5.1

Roughness length for different surfaces

\begin{tabular}{|c|c|}
\hline Surface type & $\begin{array}{ll}z_{0} \tilde{\mathrm{n} m} \\
\end{array}$ \\
\hline Grass (1 cm height, meadow) & 0,1 \\
\hline Grass (airport) & 0,45 \\
\hline Grass (prairie) & 0,65 \\
\hline Grass (artificial, 7,5 cm height) & 1,0 \\
\hline Grass (dense to $10 \mathrm{~cm}$ height) & 2,3 \\
\hline $\begin{array}{l}\text { Mowed grass } 1,5 \tilde{\mathrm{nm}} \text { height } \\
\begin{array}{l}3 \tilde{\mathrm{n} m} \text { height } \\
4,5 \tilde{\mathrm{n} m} \text { height at } U=2 \mathrm{~m} / \mathrm{s} \\
\text { at } U=6-8 \mathrm{~m} / \mathrm{s}\end{array}\end{array}$ & $\begin{array}{l}0,2 \\
0,7 \\
2,4 \\
1,7\end{array}$ \\
\hline Grass (sparse, to 50 ñm) & 5,0 \\
\hline Wheat stubble (18 ñm; Ềnsas) & 2,44 \\
\hline $\begin{aligned} \text { High grass }(60-70 \tilde{\mathrm{nm}}) \text { at } U & =1,5 \mathrm{~m} / \mathrm{s} \\
\text { at } U & =3,5 \mathrm{~m} / \mathrm{s} \\
\text { at } U & =6,2 \mathrm{~m} / \mathrm{s}\end{aligned}$ & $\begin{array}{l}9,0 \\
6,1 \\
3,7\end{array}$ \\
\hline Grass (with sparse bush and trees Solsbery Plane, UK) & 4,0 \\
\hline $\begin{array}{l}\text { Inhomogeneous surface with alternating sections covered by grass, bush, trees } \\
\text { etc. by measurements at masts in Obninsk (Kaluga region) and } \\
\text { Round Hill (South Dartmuth, Massachusetts) }\end{array}$ & $\sim 10$ \\
\hline Vegetation of 1-2 m height (c. Canaveral, Florida) & 20,0 \\
\hline Trees of $10-15 \mathrm{~m}$ height (c. Canaveral, Florida) & $40-70$ \\
\hline $\begin{array}{l}\text { Young oak trees of mean height } 10 \mathrm{~m} \text { by measurements in Brukhaven } \\
\text { (New York) }\end{array}$ & $\sim 100$ \\
\hline $\begin{array}{l}\text { Bush savanna } \\
\quad(25 \% \text { - trees of } 8 \mathrm{~m} \text { height; } \\
65 \% \text { - dry grass of } 1 \mathrm{~m} \text { height; } \\
10 \% \text { - burnt grass and sand) }\end{array}$ & 40 \\
\hline $\begin{array}{l}\text { Urban area with high buildings, by measurements at TV masts } \\
\text { in Leningrad and Novosibirsk }\end{array}$ & $\sim 100$ \\
\hline A large city (Tokio, Japan) & 165 \\
\hline
\end{tabular}


5.3. Calculation of the resuspension factor and resuspension rate.

Using the available data on wind speed, roughness length and other parameters mentioned in 5.1 the resuspension factor and resuspension rate are calculated with the following formulae:

$$
\begin{array}{ll}
a=\frac{2,8 \cdot 10^{-6}}{Z_{0}^{1.4}} K_{m} K_{f}\left(1-K_{w}\right) K_{a} u^{2,25} t^{-1,67}, & \text { at } u \leq 10 \mathrm{~m} / \mathrm{s} \\
a=\frac{5,8 \cdot 10^{-7}}{Z_{0}^{1.4}} K_{m} K_{f}\left(1-K_{w}\right) K_{a} u^{2} t^{-1,67}\left(0,012 u^{3}-0,65 u+8,0\right), & \text { at } 10<u \leq 15 \mathrm{~m} / \mathrm{s}
\end{array}
$$

$\alpha_{i}=(1,5 \pm 0,6) \cdot 10^{-8} \mathrm{~s}^{-1} \quad$ for the area where agricultural works are conducted;

$$
R=\frac{2,9 \cdot 10^{4} u^{1,25} t^{-1,67} \cdot K_{m} \cdot K_{f} \cdot\left(1-K_{w}\right) \cdot K_{a}}{Z_{0}^{1.4}}, \quad \text { at } u \leq 10 \mathrm{~m} / \mathrm{s}
$$

$$
R=\frac{6,1 \cdot 10^{-5} u^{5} t^{-1,67} \cdot K_{m} \cdot K_{f} \cdot\left(1-K_{w}\right) \cdot K_{a}}{Z_{o}^{1.4}}, \quad\left(0,012 u^{3}-0,65 u+8,0\right), \quad \text { at } 10<u \leq 15 \mathrm{~m} / \mathrm{s}
$$

5.4. Flux of radioactive dust from the underlying surface.

The flux of radioactive dust from the underlying surface $Q$ is written as

$$
Q=\alpha A
$$

by substituting (5.1) for $\alpha$, we get

$$
Q=\frac{2,8 \cdot 10^{-6} \cdot t^{-1.67} K_{f i} \cdot K_{m} \cdot K_{a} \cdot\left(1-K_{w}\right) \cdot u^{2,25}}{Z_{0}^{1.4}} \times A
$$

For (5.2) the formula is derived in a similar way.

The flux of radioactive dust due to mechanical resuspension is calculated by the formula

$$
Q=\alpha_{i} \cdot A
$$

Thus, using the measured and calculated wind speeds, roughness length, with allowance for the number of days since the accident, moisture content and type of the underlying surface we can calculate the flux of radioactive dust from the contaminated underlying surface due to wind resuspension. 
5.5. Calculation of wind resuspension characteristics using the mass load method.

5.5.1. Input parameters for calculation with the mass load method.

$A_{s}, \mathrm{~Bq} / \mathrm{g}$ is specific radionuclides content of the underlying surface;

$A, \mathrm{~Bq} / \mathrm{m}^{2}$ is radioactive contamination density of the underlying surface;

$q_{1}, \mathrm{~Bq} / \mathrm{m}^{3}$ is radionuclides concentration in the air at height of $1 \mathrm{~m}$;

$C_{1}, \mathrm{~g} / \mathrm{m}^{3}$ is dust concentration in the air at height of $1 \mathrm{~m}$;

$u_{s}, \mathrm{~m} / \mathrm{s}$ is friction velocity;

$H, \mathrm{~m}$ is height of the surface layer.

5.5.2. Calculation of the resuspension factor, resuspension rate and flux of radioactive dust.

The radionuclides concentration in the air is calculated by

$$
q_{1}=A_{s} \cdot C_{d}
$$

Then, $R=q_{1} / A$

Considering that

$$
q_{1}=\frac{Q}{æ_{1} u_{*}} \ln \frac{H}{Z_{1}}
$$

where $æ_{1}=æ / \operatorname{Pr}, \quad æ=0,4$ is Karman constant, $\operatorname{Pr} \approx 0.85$ is Prandtle turbulent number, $z_{1}=1 \mathrm{~m}, Q$ is vertical flux of radionuclides, we get

$$
\begin{gathered}
\alpha=\frac{æ_{1} u_{*} R}{\ln H / Z_{1}} \\
Q=\frac{æ_{1} \cdot \mathrm{u}_{*} \cdot \mathrm{A}_{\mathrm{s}} \cdot \mathrm{C}_{\mathrm{d}}}{\ln \mathrm{H} / \mathrm{z}_{1}} .
\end{gathered}
$$

The dust concentration is taken from the data of the state atmospheric monitoring service as a characteristic value or year-averaged (season or month averaged).

If $q_{1}$ is known, the resuspension rate and radionuclides flux is calculated by the above formulae.

For conservative estimation the following values of the basic quantities are used:

1) if the dust concentration in the air is not known, then it is assumed that $C_{d}=100$ $\mu \mathrm{g} / \mathrm{m}^{3}$ 
2) if the information about $A_{s}$ is not available, then

$$
\grave{A}_{s}=\frac{A}{\rho_{s} \cdot \delta_{s}},
$$

where $\rho_{s}=10^{12} \mu \mathrm{g} / \mathrm{m}^{3}$ is soil density,

$\delta_{s}=0.005 \mathrm{~m}$ is thickness of the upper soil layer;

3) ageing of radionuclides is taken into account by introducing the time factor

$$
\grave{A}_{s}=\frac{A}{\rho_{s} \cdot \delta_{s}} \cdot t^{-1,67},
$$

where $t \geq 1$ is time since the beginning of the accidental release. 


\section{References}

1. Bratsert U.H.Evaporation into the atmosphere. Theory, history, applications. Translated from English. ED by A.A.Dubov, L, Hydrometeoizdat, 1985.

2. Zilitinkevich S.S. Dynamics of the atmospheric boundary layer. L. Hydrometeoizdat, 1970.

3. Vozshennikov O.I., Burkov A.I. Quasi-homogeneous model for calculating turbulent fluxes of matter from the underlying surface. Meteorology and hydrology, 15, 1992.

4. Vozshennikov O.I. Estimation of parameters of wind resuspension, Collection of works of IEM issue 57(159), 1994. 


\section{About estimation of atmospheric contamination with burning radioactive materials.}

After the zones of radioactive contamination as a result of the Chernobyl accident were formed the radioactivity of the atmospheric surface layer in these and adjacent zones was determined primarily by the processes of wind resuspension and transport of radionuclides during strong wind and due to fires. In the course of a forest fire burning products such as soot, ash and moisture are released into the atmosphere, and the concentration of radionuclides in them can exceed the permissible concentration in the air.

The radionuclides deposited in the forest around the Chernobyl NPP are distributed as follows: about $5 \%$ occur in the stock of trees, $20 \div 85 \%$ in the litter and the rest in the mineral soil layer, and with time the radionuclides content increases both in the stock and in the mineral soil layer $/ 1,2 /$.

In 1991-1994 22 major and medium size forest fires occurred in the area around the Chernobyl NPP covering 3.9 thousand hectares of forest $/ 3,4 /$. The fire risk season in this area starts when the snow cover melts and lasts till rainy autumn weather or formation of snow cover. The largest number of forest fires (65\%) occurs in spring, $25 \%$ - in the autumn and $10 \%$ in the summer.

Depending on the way of fire propagation in the forest the fires are divided into lower (55\%) and upper (30\%) level fires and others are transitional and underground. The number of major forest fires (area of more than 200 ha ) was 9\%, medium-size (from 100 to 150 ha ) $28 \%$ and local (less than 100 ha ) 63\%. The number of forest fires on the territory with ${ }^{137} \mathrm{Cs}$ contamination of more than $5 \mathrm{Ci} / \mathrm{km}^{2}$ constituted $68 \%, 23 \%$ of fires occurred on the territory with contamination level from 15 to $40 \mathrm{Ci} / \mathrm{km}^{2}$ and others - on the territory with contamination level more than $100 \mathrm{Ci} / \mathrm{km}^{2}$.

From 19 to 25 April 1996 in some areas of the Bryansk region including those affected by Chernobyl depositions forest fires occurved. The areas under the fires in hectars, their duration and ${ }^{137} \mathrm{Cs}$ contamination of fuel material are presented in Table.

By data of /4/ after the lower fire about $20 \%$ of the initial vegetation mass remains in the forest litter, with the upper fire - 70\% and with transitional 35\%. During a local forest fire the smoke plume can be as high as $0.4-1.5 \mathrm{~km}$., the plume length - to $30 \mathrm{~km}$ and the concentration of suspended smoke particles in the air $-100 \mathrm{mg} / \mathrm{m}^{3}$. During the fire the mineralization of the forest 
litter and organic matter in the upper part of the soil profile occurs which results in a hazard of wind erosion, acceleration of wash-off and infiltration of radioactive zone in the natural landscape. 
Table

Fires in the Bryansk region, 19-25 April 1996

\begin{tabular}{||c|l|c|c|c|c|c||}
\hline \multirow{2}{*}{1} & \multicolumn{1}{|c|}{ District } & \multirow{2}{*}{$\begin{array}{c}\text { Area } \\
\text { under fire }\end{array}$} & \multirow{2}{*}{$\begin{array}{c}\text { Mean } \\
\text { contamination } \\
\text { density }\end{array}$} & \multicolumn{2}{|c|}{$\begin{array}{c}\text { Activity of } \\
\text { burning products, } \\
\text { Ci }\end{array}$} & \multirow{2}{*}{$\begin{array}{c}\text { Duration } \\
\text { hour }\end{array}$} \\
\cline { 5 - 7 } & & ha & Ci/km & by (6.1) & by model /6/ & \\
\hline \hline 1 & Novozybkovsky & 3,4 & 15 & 0,029 & 0,025 & 5 \\
\hline 2 & Krasnogorsky & 675 & 10 & 3,847 & 3,400 & 65 \\
\hline 3 & Pogarsky & 20 & 1 & 0,011 & 0,010 & 11 \\
\hline 4 & Zlynkovsky & 7 & 25 & 0,100 & 0,090 & 7 \\
\hline 5 & Unechsky & 6,6 & 0,3 & 0,001 & 0,001 & 6 \\
\hline 6 & Trubchevsky & 50 & 0,6 & 0,017 & 0,015 & 18 \\
\hline 7 & Mglinsky & 6,6 & 0,2 & 0,001 & 0.001 & 6 \\
\hline 8 & Klintsovsky & 12,4 & 0,4 & 0,003 & 0,025 & 9 \\
\hline 9 & Kletnyansky & 22,3 & 0,2 & 0,003 & 0,002 & 12 \\
\hline \hline
\end{tabular}

Hence, forest fires in the area of radioactive contamination is an important factor of radioecological risk due to

- external exposure to gas-aerosol smoke cloud and a trace of burning radioactive materials on the soil;

- internal exposure due to inhalation of radioactive smoke and consumption of food contaminated by radionuclides.

For calculation of the activity of volatile fire products the following data need to be known:

type of the fire (lower, upper etc);

burning material contamination density, $A_{s}, \mathrm{~Bq} / \mathrm{m}^{2}$;

fire length $T$, hour;

coefficient accounting for the content of volatile particles in the burning products $\varepsilon, \%$;

fire area $S, \mathrm{~m}^{2}$.

If the coefficient of the content of volatile particles in the burning products has not been specified, its value is taken to be $\varepsilon \approx 3.5 \%$ for the forest litter burning ( with moisture of $40 \%$ ) and $\varepsilon \approx 5.7 \%$ for burning of pine branches and needles (moisture $15 \%$ ).

The release strength for volatile burning products $N$ is determined by the formula 


$$
N=S \cdot \varepsilon \cdot A_{s} / T, \mathrm{~Bq} \mathrm{~s}^{-1}
$$

activity of burning products:

$$
A=S \cdot \varepsilon \cdot A_{s}, \text { Bq. }
$$

As an example, let us consider the fire forest in the Bryansk region in 1996. The data derived with (6.2) are given in Table. It also contains the activities of burning products calculated with 3-D Lagrangian model of atmospheric transport /6/.

The data in the Table, except the Klintsy district, are in good agreement, which lets us recommend formula (6.2) for estimating the activity of burning products formed during forest fires.

Thus, the parameters required for estimation of activity of forest fires burning products have been derived. Estimation was made based on specific data of forest fires in the Bryansk region in April 1996. It has been shown that formula (6.2) can be used for estimating the activity of burning products. 


\section{Reference}

1. Azarov S.I. Atmospheric contamination of ${ }^{137} C s$ during forest fires in the Chernobyl zone. Radiation biology. Radioecology, V.36, issue 4. 1996.

2. Radiogeochemistry in the zone affected by the Chernobyl accident. Ed by E.V.Sobotorich. Kiev, Nauk. dumka, 1993.

3. Landscapes of the Chernobyl zone and their estimation based on radionuclides migration. Ed by A.M.Marinich, Kiev. Nauk. dumka, 1994.

4. Odnolko A.A. Study of secondary radiation hazard during fires at facilities of increased radionuclides contamination. Abstract of dissertation for Cand, Tech. Sciences M VIPTSH MVD RF, 1995.

5. State of the environment in the Belorus. Ecological bulletin Ed. by B.F.Loginov, Minsk, 1994.

6. Vakulovsky S.M., Shershakov V.M., Golubenkov A.V., Baranov A.Yu., Borodin R.V., Bochkov L.P., Godko A.M., Kosykh V.S., Krymova N.V., Meleshkin M.A. Computer information provision of tasks of analysis of the radiation situation in the territories contaminated after the Chernobyl accident. Bulletin "Radiation and risk”, issue 3 1993, ISSN 0131-3878. 


\section{Conclusion}

The performed analysis of the literature data on wind resuspension of radionuclides into the atmosphere from the underlying surface has demonstrated that

- data are available on the resuspension factor and resuspension rate obtained by measurements;

- approximation expressions accounting for the change in wind resuspension factor with time, and resuspension rate dependence on roughness length and wind speed have been derived;

- the average effectiveness of mechanical resuspension according to the data of 1994 is $(1,5 \pm 0.6) 10^{-8} \mathrm{~s}^{-1}$;

- the mass load method is workable.

The results of the performed study include

- Expressions for the resuspension factor and resuspension rate have been derived including their dependence on time since the accident, wind speed, roughness length, type of the underlying surface, moisture of the soil, intensity of anthropogenic activity.

- It has been shown that the wind resuspension rates derived in this work and those based on experimental measurements are in good agreement.

- It has been found that the correlation factor for the calculated and experimental data on the wind resuspension is 0.9 .

- It is recommended that equations (4.18) and (4.19) are used for calculating the resuspension factor and resuspension rate at large wind speeds and roughness length and in other cases - (4.16) and (4.17) should be used. 


\section{APPENDIX}

\section{Description of program module RESUSP}

Program module writen in FORTRAN/9000 calculates next quantities (output variables):

$\mathbf{R}$ is resuspension factor;

alpha is resuspension rate;

$\mathbf{Q}$ is flux of radioactive dust from the surface.

Input variables are subdivided into essential, which are always used in program (their definition is compulsory) and optional ones. Optional variables (friction velocity Udyn, height of surface layer Hsfl) are estimated with conventional parameterization or by default. Another optional variables (specific radionuclides content in the upper soil layer AmSoil, radionuclides concentration in the air A1mAir, dust concentration in the air CAir) are used only if experimental data are available direct assessment of resuspension characteristics without using of parameterizations.

Two different parameterizations are used for calculation of factor $\mathbf{R}$ (and accordingly for alpha and Q). The parametrization is changed when wind speed goes beyond the value of 10 $\mathrm{m} / \mathrm{s}$. Also there is a switch (mach) for choosing specific definition of alpha and $\mathbf{Q}$ in the region where agricultural machines operate. 


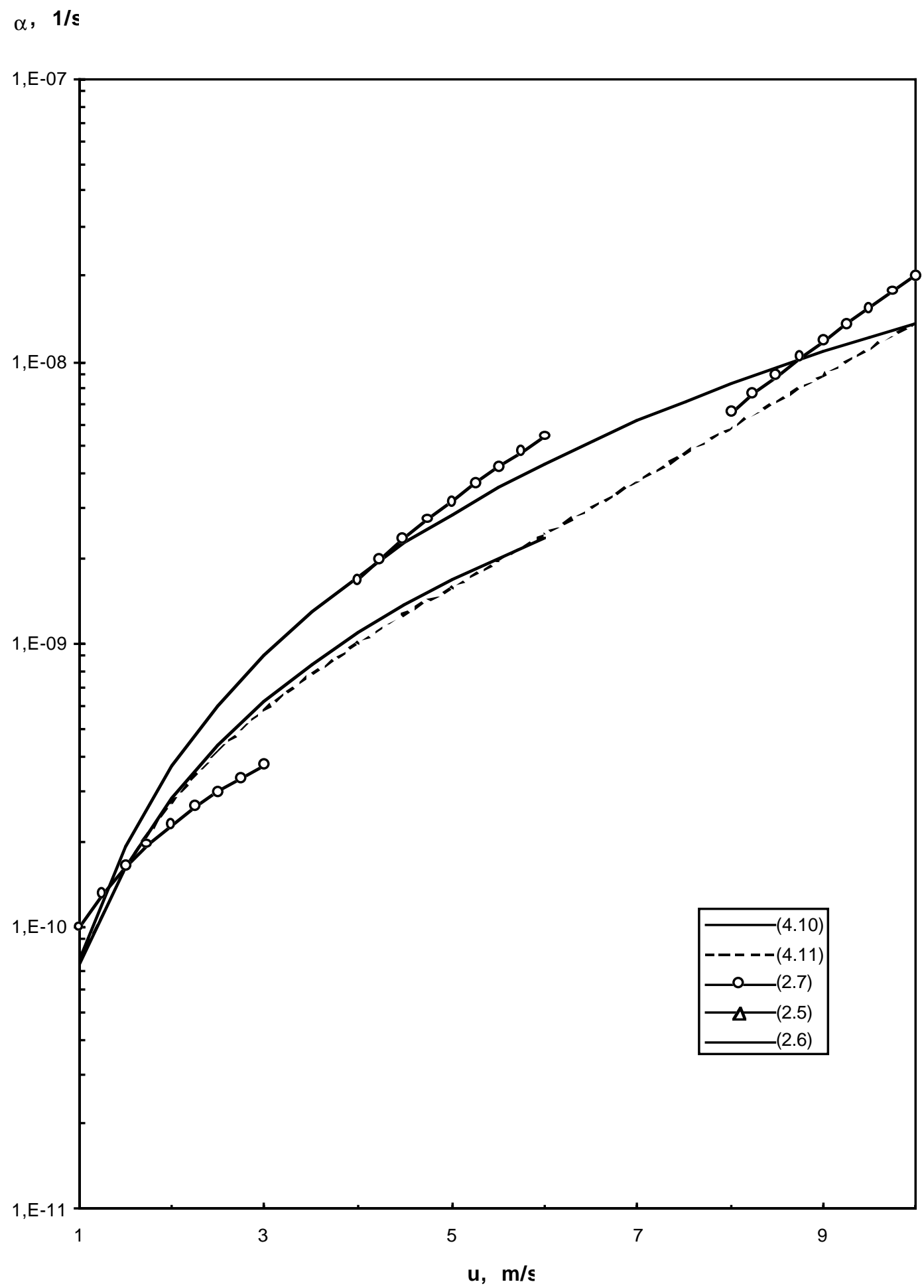

Fig.4.1. Wind speed dependence of resuspension rate calcu various approximations. 


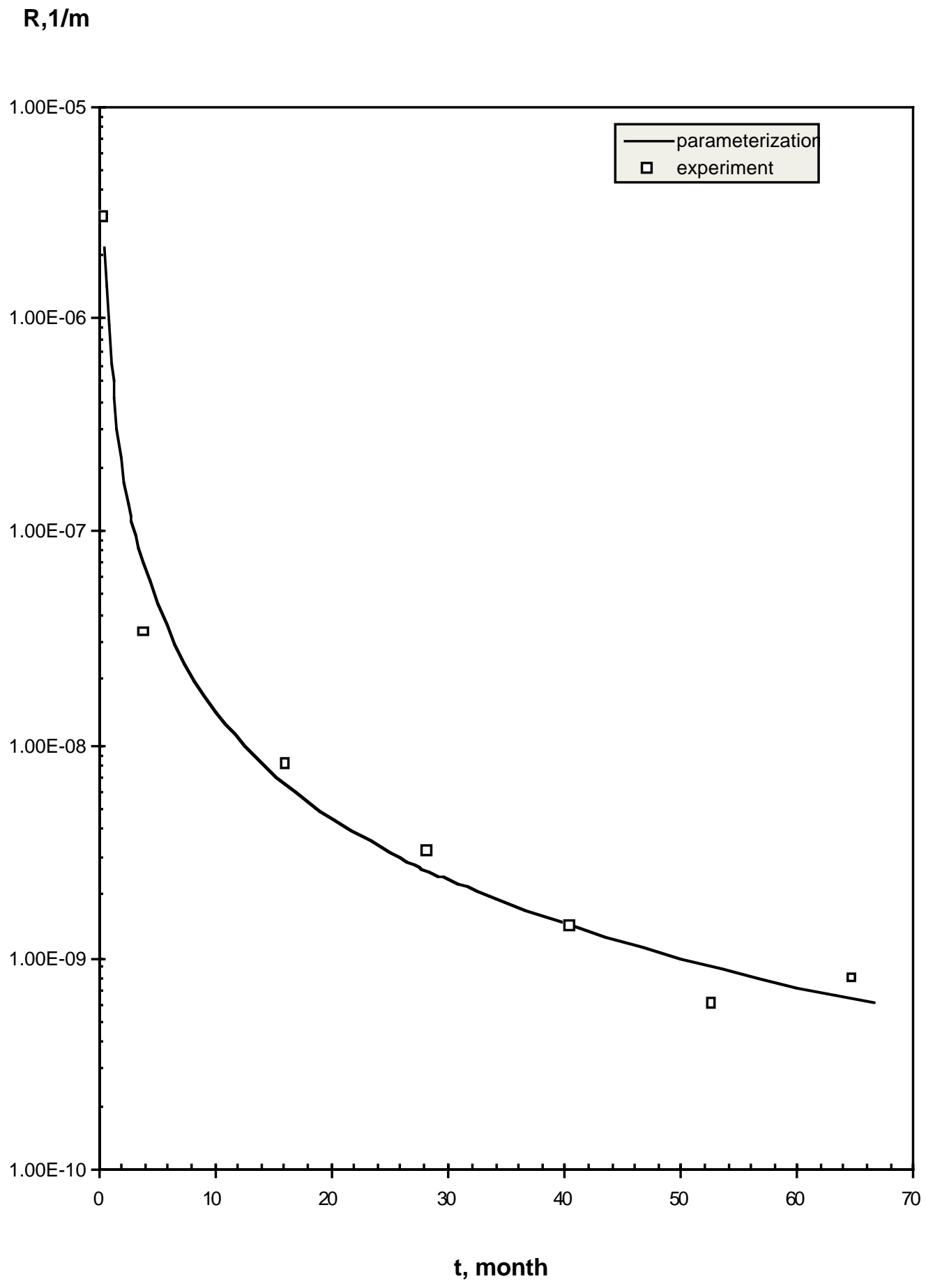

Fig.4.2. Time-dipendence of the res 


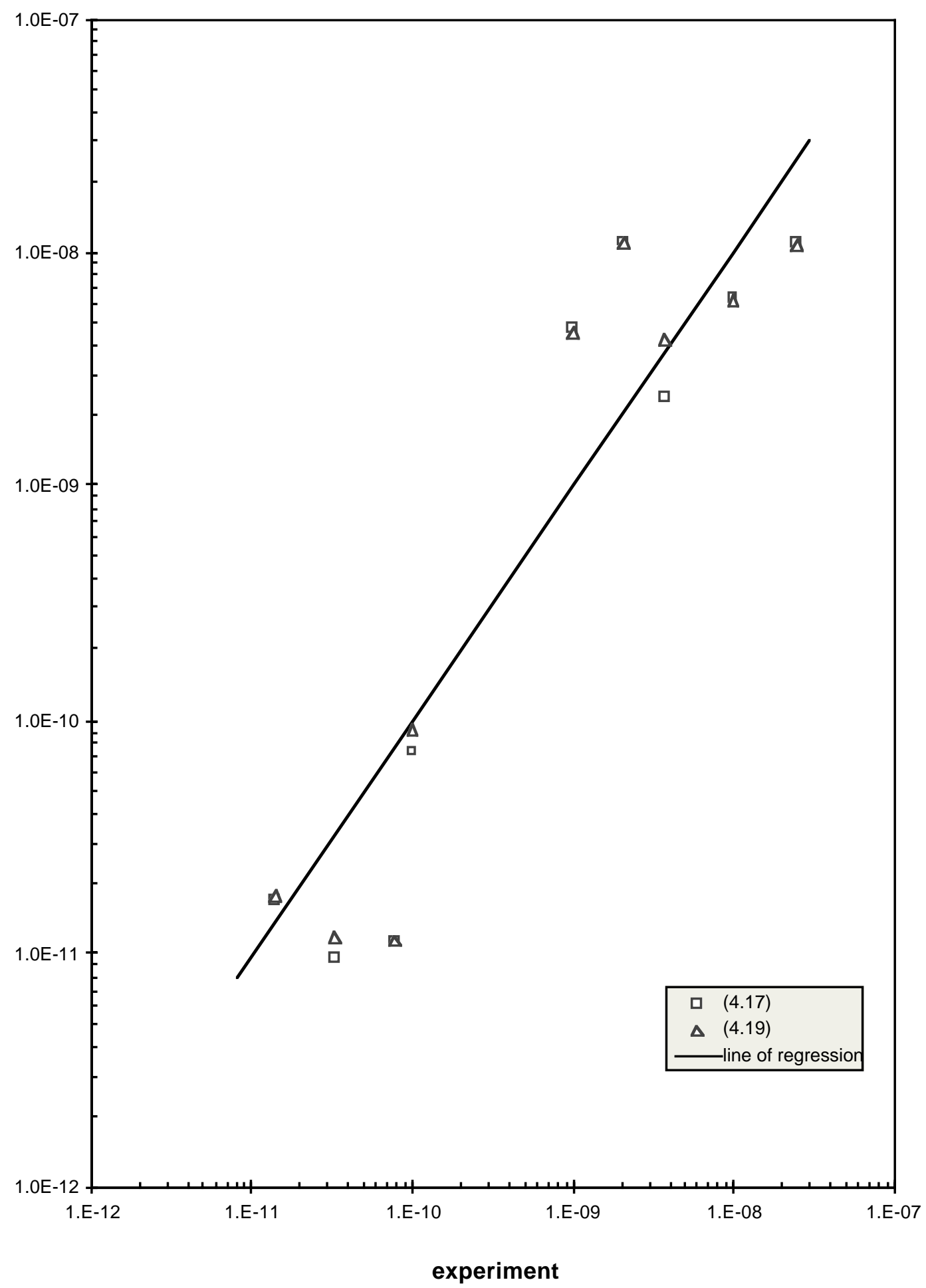

Fig.4.3. Resuspension ratted/s. 


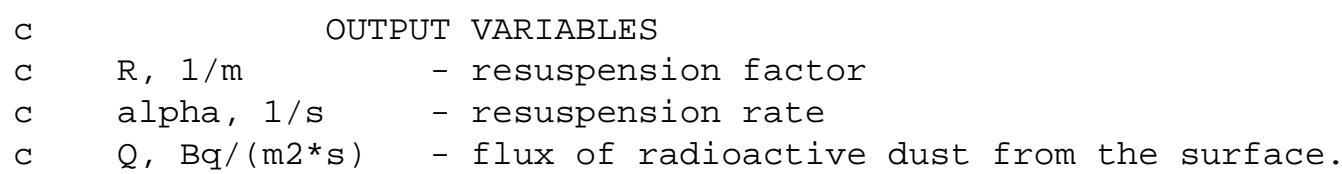

C

C

C

C

C

C

C

C

C

C

Sunday

C

C

C
SPECIFICATION OF INPUT VARIABLES

- number of days after an accident ( $t>=12)$;

- wind speed on height $10 \mathrm{~m} \mathrm{(} 1=<\mathrm{u}=<15)$;

- friction velocity (optional);

- height of the surface layer (optional);

- roughness length $(\mathrm{z} 0=<0.1)$;

- average height of roughness components;

- parameter of moisture of soil, it has following values:

1 - near saturated soil moisture content

2 - field capacity

3 - wilting point content

4 - hydroscopic coefficient

forest $\quad-$ a switch for accounting for occurrence of forest in the region ( 0 or 1 )

(this parameter is used only during the first year after an accident);

- part of the surface covered with snow or water (from 0 to 1);

- coefficient of anthropoogenic activities (1 - outside and inside a town on weekends

1.3 - inside the town on other days);

mach - attribute of presence of agricultural machinery operation (=1 when such activities take place);

AdSoil, Bq/m2 - soil surface contamination density in $t$ days after accident;

AmSoil, Bq/g - specific radionuclides content in the upper (1 sm) soil layer in $t$ days after an accident (optional);

AlmAir, Bq/m3 - radionuclides concentration in the air at height of $1 \mathrm{~m}$ in $t$ days after an accident (optional);

CAir, $g / m 3$ - dust concentration in the air at height of $1 \mathrm{~m}$ in $t$ days after an accident (optional).

subroutine $\operatorname{RESUSP}(\mathrm{R}$, alpha, Q)

real $\mathrm{Kw}, \mathrm{Ka}, \mathrm{Kf}$, Ws (4) 


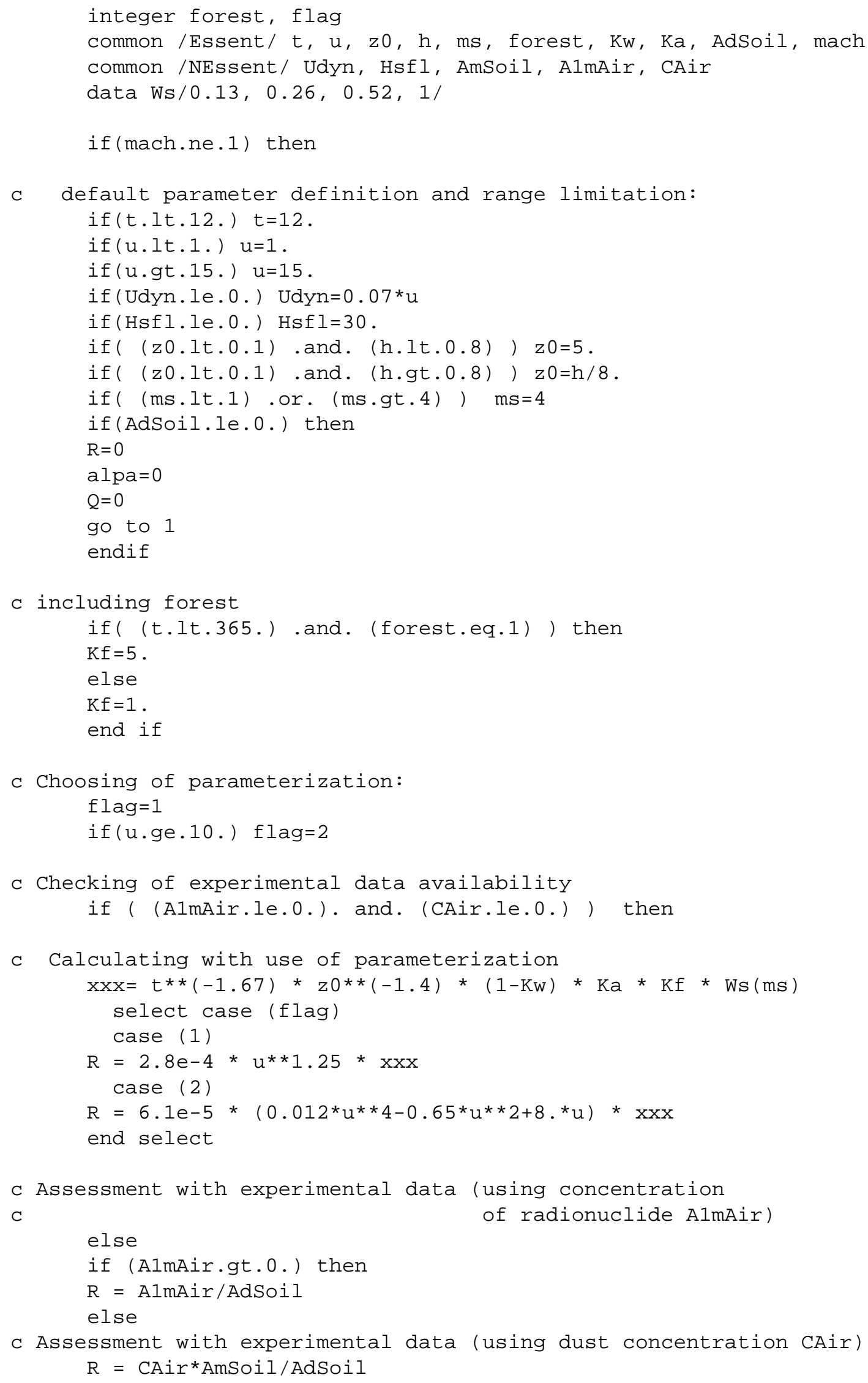




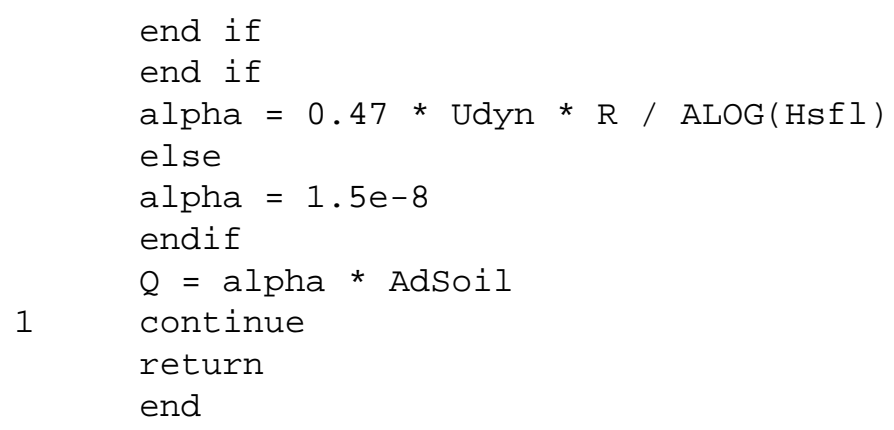

C Example of calling module RESUSP

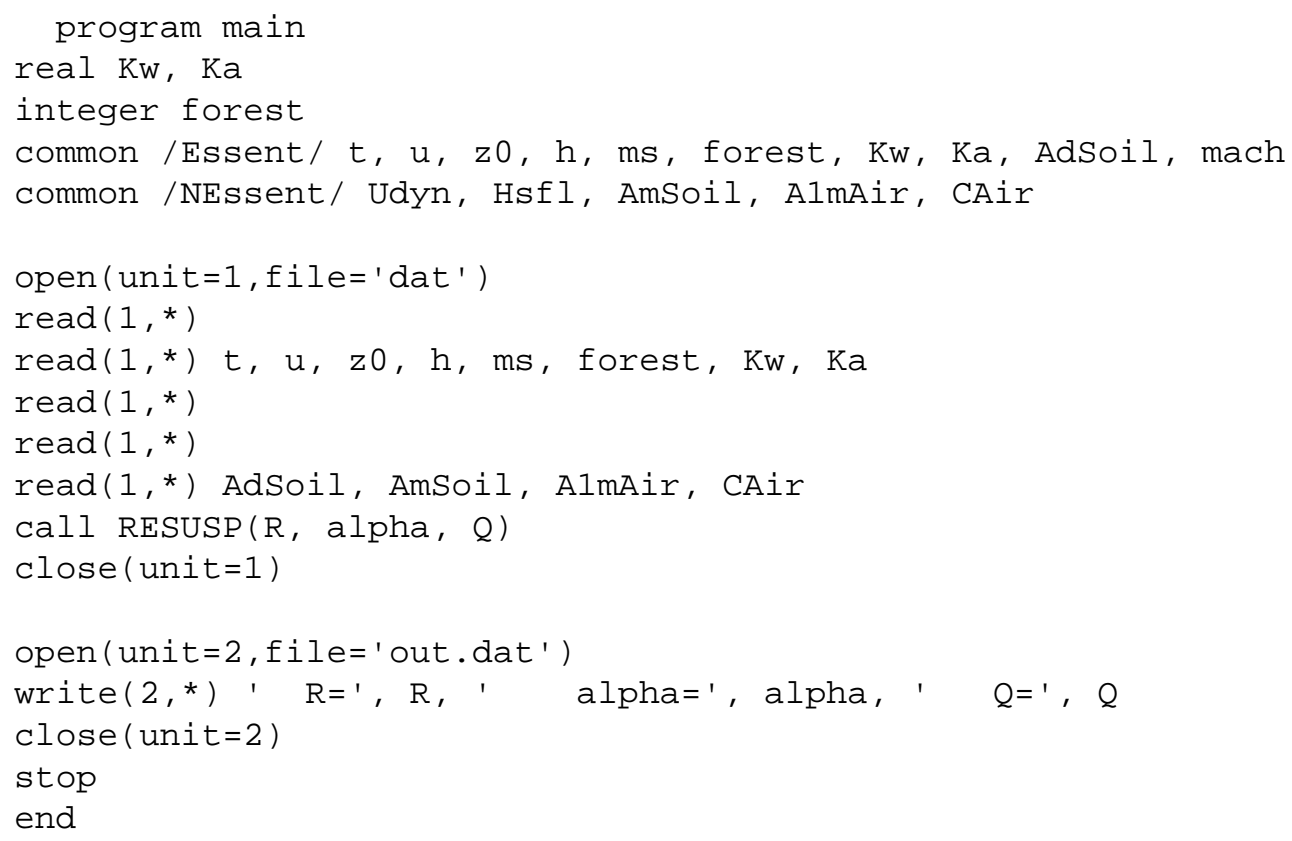




\begin{tabular}{|c|c|c|c|c|c|c|}
\hline$t$ & zo & $\mathrm{h}$ & $\mathrm{ms}$ & forest & $\mathrm{Kh}$ & $\mathrm{Ka}$ \\
\hline 1000 . & 5 . & 0. & 4 & 0 & 0 . & 1 \\
\hline AdSoil & AmSoil & & Air & CAir & & \\
\hline $5 . e 5$ & 0 . & & & 0 . & & \\
\hline
\end{tabular}




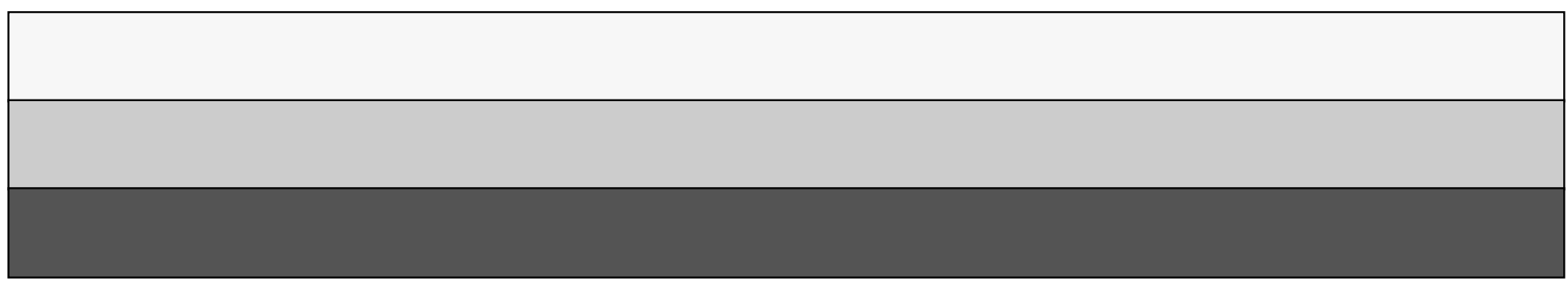

